\title{
Good Skills in Bad Times: Cyclical Skill Mismatch and the Long-term Effects of Graduating in a Recession
}

\author{
Kai Liu \\ Kjell G. Salvanes \\ Erik Ø. Sørensen*
}

May 23, 2015

\begin{abstract}
We show that cyclical skill mismatch, defined as mismatch between the skills supplied by college graduates and skills demanded by hiring industries, is an important mechanism behind persistent career loss from graduating in recessions. Using Norwegian data, we find a strong countercyclical pattern of skill mismatch among college graduates. Initial labor market conditions have a declining but persistent effect on match quality and skill mismatch early in their careers. Match quality of the first employment may explain up to half of the short-term and most of the long-term earnings loss from graduating in a recession. (JEL E32, J31, $\mathrm{J} 62$ ).
\end{abstract}

\section{Introduction}

There is a growing literature showing that labor market conditions at the time of labor market entry have large and persistent negative effects on careers. For example, recent papers by Kahn (2010) and Oreopoulos, von Wachter, and Heisz (2012) show that

*All authors: NHH Norwegian School of Economics, Department of Economics, Helleveien 30, 5045 Bergen, Norway. Emails: Kai.Liu@nhh.no, Kjell.Salvanes@nhh.no, Erik.Sorensen@nhh.no. Corresponding author: Erik $\varnothing$. Sørensen, phone (+47) 559594 36. We thank the editor and two anonymous referees for their constructive suggestions, and also Peter Gottschalk, Robert Moffitt, and the participants at several seminars and conferences for helpful comments and discussions. This research is supported by the Research Council of Norway Grant 202445. 
college graduates in North America suffer persistent declines in earnings lasting up to 10 years. Similar evidence has been found using data sets from other countries or groups of graduates. ${ }^{1}$ Understanding the mechanisms driving these persistent career losses is essential to the design of government employment programs aimed at helping young workers.

While much is known about the overall magnitude and heterogeneity of these highly persistent career losses, less work has been done on the mechanisms driving the losses. It is difficult to explain the persistence in career losses from presumably short-lived labor market shocks. The literature has pointed out that the quality of first job placement is important in explaining the long-term career losses. Kwon, Milgrom, and Hwang (2010) find that those who graduate in booms are promoted faster, even when conditional on proxies for productivity. Oreopoulos et al. (2012) find that a lower quality first job can explain the persistence of earnings losses, but only when combined with search frictions that intensify with age. Hagedorn and Manovskii (2013) and Frühwirth-Schnatter, Pamminger, Weber, and Winter-Ebmer (2012) provide evidence that idiosyncratic match quality is affected by the tightness of the labor market. Closely related to our paper, a recent paper by Altonji, Kahn, and Speer (2014) finds that the early careers of higher-skilled majors in the US are less sensitive to labor market conditions at graduation.

We add to this literature by showing that skill mismatch, which we understand as mismatch between the skills supplied by college graduates and the skills demanded by hiring industries, is another important mechanism behind the persistent career loss from graduating in recessions. We analyze the matching over the business cycle between heterogeneous skills within each cohort of graduates and heterogeneous demand for skills by hiring industries. We define the type of skill supplied as the field of study in college. Mismatch occurs when a worker is matched to an industry that does not value her/his skill, and we operationalize this using relative wage premia across college majors and industries (as such, our paper use a different definition of mismatch than the literature that focus on mismatches in the level of education (Leuven and Oosterbeek, 2011)).

\footnotetext{
${ }^{1}$ See Oyer (2006) (US), Brunner and Kuhn (2014) (Austria), Kondo (2007); Genda, Kondo, and Ohta (2010) (Japan) and Stevens (2007) (Germany). Another related strand of literature focuses on the long-term impact of initial labor market conditions facing youth or low skilled workers (Gardecki and Neumark, 1998; Ellwood, 1982; Neumark, 2002; Burgess, Propper, Rees, and Shearer, 2003; Raaum and Røed, 2006; Liu, Salvanes, and Sørensen, 2014). In that literature, there seems to be a reasonable consensus that there is a persistent effect of youth unemployment on a worker's career later in life.
} 
That students find jobs in industries they did not train for is in itself not problematic. Presumably, they would only want to do so if this industry offered better career prospects than the industry they trained for, and if new graduates have access to consumption smoothing, school-to-job transitions that are classified as mismatches will be efficient. But if new graduates cannot efficiently smooth consumption, they might be forced to accept jobs that are bad long-term matches. They might not be able to afford 'investing' in a low-paying job of the sort they trained for, even if there are long-term complementarities between schooling and experience. In such a case, mismatch might be inefficient. ${ }^{2}$

Using administrative matched employer-employee panel data from Norway, we first document that, like many other countries, an average Norwegian college graduate has persistent earnings loss from bad initial labor market conditions. Interestingly, the negative effects are more pronounced among graduates whose fields of study lead to jobs with more cyclical demand, i.e., the private sector. College graduates with degrees aimed at the public sector (education and health) which is more insulated from business cycle shocks, show much less persistence of the initial (and smaller) earnings loss. Using our specification of mismatch (wage premia), we show that there is a strong counter-cyclical pattern of skill mismatch among college graduates entering the labor market. A typical recession, with a rise in the unemployment rate by three percentage points, implies an initial increase of about 30 percent in the probability of mismatch. The effects of the initial labor market conditions on mismatch decline over time but remain highly persistent over early careers, suggesting that some graduates never switch back to the "right" industry. ${ }^{3}$ Our results survive a range of the robustness checks including students' timing of graduation and region of graduation relative to the regional unemployment rates.

Establishing the persistence of the effects of graduating in a recession and that our measures of mismatch are counter-cyclical, we followed the literature by using aggregate cohort-region-time level data. To understand how much the negative wage effect can be explained by match quality of the first employment, we exploit the advantage

\footnotetext{
${ }^{2}$ In an online appendix, we illustrate this in a two-period model in which heterogeneous skills depreciate if not used. In this setting, transitory shocks to productivity can have long-term consequences because of the skill dynamics. In our model, with credit constraints and a minimum level of consumption, mismatch can be inefficient, and there is more such inefficient mismatch in recessions.

${ }^{3}$ In addition, we use an alternative definition of mismatch by using relative worker flows across majors and industries. These results support our main finding for wages in that a typical recession leads to a 9 percent reduction in the average quality of matches.
} 
of individual-level data by including individual-level variables to control for match quality of the first employment and compositional changes over the business cycle. We find that both the short- and long-term effects of initial labor market conditions are substantially lower once the match quality of the first employment is controlled for. For instance, the effect on log earnings among men majoring in private-sector fields is reduced by almost one half in the first two years after graduation. Initial local labor market conditions also have a much less persistent effect during the early stages of workers' careers. In comparison, controlling for differences in the composition of graduates over the business cycle alone using proxies for cognitive ability has minimal impacts on the effects of initial conditions. These findings suggest that the cyclical mismatch of college graduates could be an important driving force behind the persistent career loss.

The paper is organized as follows. Section 2 explains our empirical strategy and relates it to the literature. In Section 3 we present our data and situate our sample in the context of the Norwegian business cycle before we provide our results in Section 4, some tests of robustness in Section 5, and concluding remarks in Section 6.

\section{Empirical Strategy}

In this section we describe our estimation strategy to identify the short- and long-term effects of initial labor market conditions on skill mismatch and on a range of other labor market outcomes.

\subsection{Estimating the Short- and Long-term Effects of Initial Labor Market Conditions}

We approximate initial labor market conditions using the regional unemployment rate at the time of graduation. Following Kahn (2010) and Oreopoulos et al. (2012), we use the variations in business cycle conditions across regions within a cohort (above and beyond the regional effects captured by the region fixed effect) to identify the causal effects of graduating in recessions. The outcome variable in period $t$ for a graduating cohort $c$ from region $r$ is determined by the following linear model:

$$
y_{c r t}=\beta_{1}+\sum_{e} \beta_{2}^{e} U_{c r 0}+\phi_{t}+\theta_{r}+\gamma_{e}+\gamma_{e} \times \theta_{r}+\xi_{c}+u_{c r t},
$$


in which $\theta_{r}, \xi_{c}, \gamma_{e}$ and $\phi_{t}$ are fixed effects for region of the college at the time of graduation, year of graduation (or graduating cohort, $c$ ), years of potential labor market experience and calendar year, respectively. Cohort fixed effects capture national changes in the quality of graduates. Regional fixed effects capture the permanent characteristics of the region. $\gamma_{e} \times \theta_{r}$ captures different experience profiles by college region. $U_{c r} 0$ is the regional unemployment rate measured at the time of graduation and the region of the graduating school. The coefficients on the initial unemployment rate, $\beta_{2}^{e}$, are allowed to vary with the level of potential experience. The estimate of $\beta_{2}^{e}$ using ordinary least squares identifies the short- and long- term changes in experience profiles from region-cohort-specific variations in unemployment rates, given the regular evolution of the regional unemployment rate faced in the future. ${ }^{4}$ The main identifying assumption is that the variations in local unemployment rates arise from changes in aggregate labor demand that are uncorrelated with the characteristics of different graduation cohorts. In Section 5, we conduct a range of robustness checks to show that our results are unaffected by selective timing of graduation and selective region of the first employment.

As the main regressor $U_{c r 0}$ varies by region of graduation and cohort, we first cluster our panel data into cells defined by cohort, calendar year, and region of graduation. We then estimate equation (1) weighted by the corresponding cell sizes, and cluster the standard errors at region of graduation and cohort level. We drop one additional cohort effect from the regression in order to identify the cohort, experience, and year effects separately.

\subsection{Measuring Skill Mismatch}

One of the key ingredients of estimation is to define which industries are good matches and which industries are bad matches for graduates of a given major. While it is common perception that the finance industry is a good match for students majoring in business, we are not aware of any studies that aim to quantify the quality of matches between college major and industries directly from micro data. Based on our conceptual framework, we know that to measure skill mismatch, we need to estimate the vector of efficiency units in different industries for each field of study $m\left(\boldsymbol{\omega}_{m}=\left\{\omega_{m}^{1}, \ldots, \omega_{m}^{J}\right\}\right)$.

\footnotetext{
${ }^{4}$ As the current state of regional labor markets continues to influence earnings of more experienced workers, another estimate of interest is isolating the effect of labor market conditions at entry net of subsequent effects on earnings from exposure to a possibly prolonged recession. We discuss this issue in Section 5.3 of the paper.
} 
Our baseline approach is to estimate $\omega_{m}$ from the following regression: ${ }^{5}$

$$
\log y_{i 1}=\sum_{m} \omega_{m c}^{j} I_{i m}+X_{i} \beta_{c}^{j}+\varepsilon_{i}
$$

where $y_{i 1}$ are the earnings of individual $i$ in the first year since graduation, the superscript " $j$ " stands for industry of the first employment, $I_{i m}$ is an indicator variable equal to one if the individual's field of study is $m$, and the subscript " $c$ " stands for the graduation cohort. $X_{i}$ includes the county of residence fixed effects, a full-time job indicator, and the gender of the worker. A regression is estimated for each industry of initial employment and graduation cohort separately, yielding a set of industry-cohort-specific wages paid $\left(\left\{\omega_{m c}^{j}\right\}\right)$ for each major $m$, industry $j$, and cohort $c .{ }^{6}$ We then rank the set of premia $\left\{\omega_{m c}^{j}\right\}_{j=1}^{J}$ within each major-cohort cell. The rank, denoted by $R_{m c}^{j}$, is our proxy for the quality of the worker-industry match. ${ }^{7}$ We also define a skill mismatch indicator based on a cutoff value of the rank:

$$
M_{m c}^{j}=1\left(R_{m c}^{j} \leq 3\right)
$$

where, if an individual from major $m$ is employed by any of the industries paying the three lowest wage premia, the individual is mismatched. ${ }^{8}$

For a given major of study $m$, our objective is to identify the entire vector of efficiency units over all industries, holding the (observed and unobserved) composition of workers constant in each industry. Ideally, mismatch should be defined using industryspecific skill premia identified from potential outcomes. However, because there are many industries, the data demands for instrumental variables are very high: for each industry it is necessary to find a variable that is conditionally random, shifts the probability of choosing that industry relative to the other options, and does not directly affect the outcome variable of interest. In our regression in equation 2 , we include many observable characteristics in $X_{i}$ and use only the earnings in the first year after graduation,

\footnotetext{
${ }^{5}$ This approach is similar to Gottschalk and Hansen (2003), who classify noncollege and college occupations according to estimated wage premia paid to college-educated workers.

${ }^{6}$ The cohort interaction is intended to capture major/industry-specific labor demand changes (such as the skill-biased technology change) which may affect the estimated wage premia and in turn, the industry rank. For each regression of graduating cohort $c$, the sample used for estimation includes a fiveyear moving window centered around the cohort of graduation (i.e. cohorts $c-2, c-1, c, c+1, c+2$ ). The five-year moving window means that we remove the effects of any transitory industry-specific shocks on first earnings ( $\alpha_{t}^{j}$ in the model).

${ }^{7}$ If the worker is unemployed for an entire calendar year, no rank is assigned.

${ }^{8}$ In Section 4, we conduct robustness checks using alternative cutoffs.
} 
hoping that any remaining bias is small. Note that our definition of mismatch is based on the ordering of the industry-specific wages, which puts fewer restrictions on our identification strategy: our measure of mismatch is unbiased so long as the selection bias does not change the ordering of the skill premia.

As a robustness check, we also use an alternative definition of skill mismatch based on worker flows from different college majors into different industries. This choicebased approach does not require the estimation of the skill premia. We explain this approach in detail in Section 5.2.

\section{Data and Sample Selection}

The data on workers used in our study are derived from administrative registers and prepared for research by Statistics Norway. The data covers all Norwegian residents aged 16-74 years old in the period from 1986 to 2007. We have information about employment relationships, labor income, educational attainment, field of education and date of completion, labor market status, and a set of demographic variables such as gender, age, experience, and marital status. A unique person identifier allows us to follow workers over time. Likewise, each worker is matched to a firm, allowing us to identify each worker's employer. Regional labor market characteristics such as unemployment rates are also available.

The main focus of the study is college graduates with 13-16 years of education who graduate between the ages of 20 and 30 . We have the exact date of graduation and the municipality of the college attended for students. We also have the exact date of initial enrollment and whether students take a shorter or longer time than the scheduled time for a program. This is important when calculating whether students are delaying finishing or rushing to finish depending on the business cycle.

The sample used in our main analysis is constructed by first identifying the cohorts graduating between 1988 and 2003. We then drop those who became self-employed or returned to school and people for which observations are missing. In our main sample, we include both men and women. We focus on the first 10 years following graduation from college.

We define eight categories of field of study based on the international standard for education (Statistics Norway, 2003). These fields of study are given in Table 1. We fix the field of study at the graduation year. We drop people whose education relates 
to primary industries or who are in non-categorized fields. The other element used when calculating the mismatch index is the eight industries defined using the ISIC classification (Statistics Norway, 1983). ${ }^{9}$ Our measure of earnings is the sum of pretax market income (from wages and self-employment) and work-related cash transfers, such as unemployment benefits, sickness benefits, and parental leave benefits.

We use regional (county) level unemployment rates in our regression analysis. The unemployment rate is taken from the Norwegian Labor and Welfare Organization (NAV). We exploit one major economic downturn and one smaller downturn plus two upturns that took place in Norway during the sample period. The national unemployment rate is reported in Figure 1 for the period 1986-2006. Particularly interesting for this analysis is the severe recession that took place in Norway at the beginning of the data period starting in 1988/89. The downturn lasted until 1993, when unemployment rates began to decrease. This is the deepest and longest-lasting downturn in Norway since WWII. The unemployment rate rose from 1.5 percent to 5.5 percent, which is a historically high rate in Norway. ${ }^{10}$ In addition to the unemployed, about 3 percent of the labor force were on various labor market programs. One reason why the recession lasted so long was that a banking crisis occurred in 1991/92 when several large private banks had to be saved by the government (Steigum, 2010). Following this recession, growth and employment picked up and a boom occurred around 1998 during which the unemployment rate decreased to 2.4 percent. The recovery flattened out in 1998, but lasted until 2001. In 2001-2003 there was a mild recession before a new and strong expansion started. Figure A3 in the online shows the time series of annual unemployment rates at the regional level, which our identification relies on. The figure displays a high degree of regional heterogeneity across regions at any given point in time.

In addition to variables related education and labor market outcomes, in subsequent analysis, we also use IQ test scores from Norwegian military records. ${ }^{11}$ Military service is compulsory for all able males in Norway. Before entering the service, their medical and psychological suitability is assessed: this occurs around their 18th birth-

\footnotetext{
${ }^{9}$ There is a trade-off in the choice of industry-field classifications. For example, to use more detailed industry classifications we would have had to combine certain fields of study in order to have a sufficiently large sample for each industry-field-year cell. To obtain a large enough sample for all industries, we merge agriculture, mining, electricity and water, and construction into one. We also separate out social services, including health and education, because this comprises 30 percent of employment.

${ }^{10}$ These rates are based on the number of fully unemployed persons registered at a national insurance office in a particular week in each year. If the annual unemployment survey data from Statistics Norway are used, the unemployment rate is about one percentage point higher.

${ }^{11}$ We explain our use of the IQ scores in Section 4.3.
} 
day. The IQ measure is a composite score from three timed IQ tests: arithmetic, word similarities, and figures. ${ }^{12}$ The composite IQ test score is an unweighted mean of the three sub-tests. The IQ score is reported in stanine (Standard Nine) units, a method of standardizing raw scores into a nine-point standard scale with a normal distribution, a mean of five, and a standard deviation of two.

\section{Estimation Results}

We begin this section by documenting the short- and long-term effects of graduating in recessions using the Norwegian data. We then provide empirical evidence that cyclical skill mismatch is an important mechanism explaining the persistent career loss. Specifically, we examine how skill mismatch changes over the business cycle, and show how the inclusion of the quality of the first match reduces the estimated effects of initial labor market conditions.

\subsection{The Short- and Long-term Effects of Graduating in a Reces- sion}

Figure 2 shows the experience profiles of log annual real earnings by cohorts. There are large variations in starting wages across cohorts (connected by dashed lines in black), which appear strongly correlated with business cycles. The initial differences gradually fade out and earnings across cohorts converge in a little over five years. Indeed, the earnings for people who have spent five years in the labor market show only minor variations over the business cycle (dashed lines in red). Figure 3 shows the experience profile of unemployment across graduating cohorts. In the first year after graduation, the rate of unemployment peaks at above 20 percent in the early 1990s and drops to below 10 percent in late 1990s as the economy recovers from the severe recession. Unemployment is more cyclical for graduates entering the labor market (black dashed line) than graduates who have been in the labor market for five years (red dashed line). These patterns are very similar to those found in studies using data

\footnotetext{
${ }^{12}$ The arithmetic test is quite similar to the arithmetic test in the Wechsler Adult Intelligence Scale (WAIS) (Sundet, Tambs, Harris, Magnus, and Torjussen, 2005; Cronbach, 1964). The word test is similar to the vocabulary test in WAIS, and the figures test is similar to the Raven Progressive Matrix test (Cronbach, 1964). See Sundet, Barlaug, and Torjussen (2004), Sundet et al. (2005), and Thrane (1977) for details.
} 
from other countries.

We then investigate the effect of initial labor market conditions on annual earnings, using the regression framework described in Section 2. Table 2 demonstrates that those who graduate in recessions suffer from significant earnings loss in the first few years after college. A one- percentage-point increase in the unemployment rate leads to six percent lower annual earnings in the first two years after graduation. The losses in annual earnings reduce to 2.5 percent by the fourth year after graduation and are small and insignificant thereafter. Compared with Oreopoulos et al. (2012), the magnitude of the initial earnings loss is quite similar, but the effects are smaller and less persistent in the long term.

In our setting with a large public sector, as mentioned, it is natural to separate out the graduates with an education basically qualifying them for public sectors such as education and health. The reason is that we expect the public sector to be more insulated from national and international business cycle shocks because both the demand for health and education are local services, and quite independent of demand shocks. Furthermore, the system of wage negotiations and labor relations are different than in the private sector (Hunnes, Møen, and Salvanes, 2008). For instance, the public sector is characterized by a very high union membership rate (90 percent as opposed to 30 percent in the private sector), and centralized wage bargaining is an important part of wage determination. Indeed, when we disaggregate the sample by dividing graduates into those majoring in fields that are more likely to work for the public sector (health and education) and those with a major in other fields, we observe large differences in terms of how they respond to bad local labor market conditions. Graduates majoring in "public" fields have temporary earnings losses that are limited to the first two years, whereas graduates from other majors suffer from much more persistent earnings losses that remain significant (at nearly 2 percent) eight years after graduation. Note that the initial earnings loss is quite similar between public- and private-sector majors (4.8 percent vs. 6.1 percent). The difference between public- and private-sector majors materializes a few years after graduation, which may reflect the different wage growth trajectories of these sectors. ${ }^{13}$

With generous social assistance and unemployment protection in Norway, workers might be more likely to choose unemployment rather than working at jobs with significant wage reductions. This is confirmed when we examine the effects on indices

\footnotetext{
${ }^{13}$ We thank an anonymous referee for pointing this out.
} 
of unemployment in the last three columns. While the effects on annual earnings are limited to the first three years, the effects on unemployment are strong and persistent. We find that a one-percentage-point rise in the local unemployment rate increases the probability of unemployment by 1.4 percentage points in the first year after college, and the effects are smaller but persistent up to eight years after graduation. Similar differences between types of majors remain when we use unemployment as the outcome variable. Compared with students majoring in education and health, graduates majoring in other fields experience a higher probability of unemployment in all periods within the first 10 years after graduation.

Given the heterogeneity in the effects of initial business cycle conditions across different types of majors, in our analysis below, we focus primarily on the graduates working in other "private" sector fields of study to explain the highly persistent earnings and employment losses.

\subsection{The Effect of Recessions on Skill Mismatch}

We first provide some descriptive statistics of the mismatch measure we use. Figure 4 plots the adjusted wage estimated from equation (2) across industry-majors over time. The unweighted mean and standard errors of adjusted wages over all years for all industries are summarized in Table 1. There are substantial differences in the wage premia paid for a given type of skill. For example, graduates with a degree in Health and Welfare are valued most in the Social and Related Community Services sector and least in the Manufacturing sector. There are also considerable variations in the wage premia for different skills within an industry. For example, the adjusted log wage for business majors in the Financing, Insurance, Real Estate and Business Services sector is 12.13, but for those majoring in Humanities and Arts, the adjusted log wage is 11.78. Figure 5 shows the unweighted average adjusted log wage for each field of study for all graduating cohorts. Overall, adjusted wages are countercyclical across all fields of study: they are lower in periods when unemployment rates were high and they rise in periods when unemployment rates were declining. Graduates majoring in Humanities and Arts have the lowest wage level, whereas graduates majoring in health are the most highly paid.

Figure 6 shows the probability of mismatch (defined using equation (3)) in the first year of graduation by cohort and fields of study. We find large variations in the probability of mismatch, both across majors and across graduation year. People majoring in 
teaching and health have the lowest level of mismatch in the sample period. For most majors, the probability of an initial mismatch is generally high during the early 1990s, falling in the late 1990s, and rising again in the early 2000s. The general pattern correlates positively with the national unemployment rate over the period. Note that, in the regression framework, this variation across cohorts will be absorbed by the cohort dummies. The cyclical variations we are exploiting are the variations across regions within a cohort and across cohorts within the same region.

To identify the cyclical variation in mismatch in a regression framework, we estimate equation (1) using mismatch as the outcome variable. This allows us to control for permanent differences across graduating regions and graduating cohorts. Table 3 reports the estimated effects of initial regional unemployment rate on match quality by years since graduation. In columns (1)-(3), we use the rank of the estimated skill premia $\left(R_{m c}^{j}\right)$ as the dependent variable. ${ }^{14}$ The estimated coefficients $\beta_{2}^{e}$ capture changes in the quality of the industry-major match over time. We find those graduating in recessions are more likely to accept jobs in low-match-quality industries than in industries they would have entered under normal economic conditions. For workers graduating in recessions, the downgrading of the industry-major match quality also appears quite persistent. Interestingly, the effects are mostly driven by graduates majoring in fields leading to careers in the private sector (column 3). Among graduates majoring in fields leading to careers in the public sector, we do not find any significant effects of initial labor market conditions on the subsequent match quality (column 2). Note that our definition of skill mismatch is fixed within each major and graduating cohort and invariant over each calendar year. The persistent effects from initial labor market conditions indicate that a substantial number of mismatched graduates did not switch to the high-match-quality industries in the long run.

In columns (4)-(6), we repeat our analysis using the mismatch indicator defined using equation (3) as the outcome variable. ${ }^{15}$ Among all graduates, column (4) clearly shows a persistent positive effect on the probability of mismatch from graduating in a recession. A one percent increase in the regional unemployment rate at the time of graduation leads to a 2.1-percentage-point increase in the probability of a mismatch in the first two years following graduation. Given that the average probability of skill

\footnotetext{
${ }^{14}$ Recall that we rank all the industries from 1 to 8 ( 8 being the highest) according to the wage premium for a given major in a given year.

${ }^{15}$ In Table A1 in the online appendix, we report the same set of estimates using alternative cutoff values to define the mismatch indicator.
} 
mismatch in the first year after graduation is 0.20 , this represents an increase of about 10 percent. The effect decreases by about one-quarter by five years after graduation, suggesting that some initially mismatched college graduates find their way back to the industries matching their skills. However, even 10 years after labor market entrance, the probability of mismatch remains nearly 1.5 percentage points higher for workers graduating during worse economic conditions. Columns (5)-(6) report results for graduates majoring in public and private fields, respectively. Graduates from the private fields are more likely to be mismatched over the entire early careers (column $6)$.

The finding that temporary macroeconomic shocks can have persistent effects on the industry-major match quality is striking. This can be explained by credit constraints interacting with skill dynamics, which can cause temporary macroeconomic shocks to generate persistent skill mismatch over the long run. ${ }^{16}$ The large difference between the effects on public- and private-sector majors can be explained if demand shocks in the public sector are less cyclical.

\subsection{Cyclical Skill Mismatch and the Long-term Effects of Gradu- ating in a Recession}

To assess whether mismatch can explain the negative effects of entering the labor market in bad times, we augment equation (1) with the match quality of the first employment and estimate it at the individual level:

$y_{i t}=\beta_{1}+\sum_{e} \beta_{2}^{e} U_{c r 0}+\sum_{e} \beta_{3}^{e} R_{i 1}+R_{i 1} \times \theta_{r}+R_{i 1} \times \xi_{c}+\phi_{t}+\theta_{r}+\gamma_{e}+\gamma_{e} \times \theta_{r}+\xi_{c}+u_{i t}$,

where $R_{i 1}$ is the match quality (i.e. the rank) fixed effect between individual $i$ and industry of employment in the first year after graduation. We allow the effect of initial match quality to vary by years of potential experience, because this alone may have a persistent effect on the outcome of interest. The interactions between initial match quality and region $\left(R_{i 1} \times \theta_{r}\right)$ and between initial match quality and cohort $\left(R_{i 1} \times \xi_{c}\right)$ allow for the effect of match quality to differ by region and cohort. Compared with the model in equation (1), the current set of parameters $\beta_{2}^{e}$ identifies the impact of initial labor market conditions, conditional on the observed match quality in the first year of

\footnotetext{
${ }^{16}$ The model in online Appendix A illustrates such a mechanism.
} 
employment. Note that the inclusion of region, cohort, and year fixed effects already captures aggregated unobserved changes at the region and cohort level and over time.

Table 4 reports the estimated effects of initial local labor market conditions. We focus on the subsample of graduates majoring in fields leading to the private sector, given that the large and persistent impacts on earnings and match quality from initial labor market conditions are much more pronounced among these individuals. As the IQ test scores are only available for men (which we use as part of a specification check at the end of this section), we further restrict our sample to male graduates only. The first column of Table 4 presents the estimated effects of initial local labor market conditions for the subsample of men majoring in private-sector fields. Similar to our previous result using all graduates in private-sector fields (Table 2, column 3 ), we find a negative effect on earnings that persists for eight years after graduation. In column (2), we add dummy variables indicating the match quality of the first employment. Column (2) shows that both the short- and long-term effects of the initial conditions are substantially lower. For instance, the short-term effect on log earnings in the first two years following graduation is lower by almost one half (from - 0.037 to $-0.019)$. Furthermore, the effect three to four years after graduation is lower by just over one-half (from -0.029 to -0.014) and the effect five to six years after graduation is insignificant. Conditional on the match quality of the first employment, initial local labor market conditions have a much smaller and less persistent effect during the early stages of workers' careers.

Ideally, we would have liked to compare those who end up in a bad match with the counterfactual outcome in a good match. This counterfactual outcome is of course not available, and the variation in worker's initial match quality $\left(R_{i 1}\right)$ that we observe is potentially endogenous for at least two reasons. First, there might be a positive sorting between industries and workers; individuals with higher unobserved ability may be more likely to stay in the "right" industry. Therefore, the unobserved ability of the individual is an omitted variable related to mismatch and labor market outcomes. Second, the unobservable component of match quality between the individual and industry may affect both wages and the observed rank of the first industry of employment (because industry of employment is an optimal choice). In Section 4.2, we show that the match quality of the first employment is negatively correlated with the initial unemployment rate. In general, we should expect the correlation between the error term and match quality of the first employment to be positive: an individual employed by a "good" 
industry probably has an above-average unobserved match quality and/or individual ability. In online Appendix B, we illustrate that these two factors lead to a positive bias (biased towards zero) of the estimated $\beta_{2}^{e}$. Note that any measurement error in our measure of match quality will tend to attenuate the coefficient on $R_{i 1}$ to zero and the associated outcome change will be incorrectly attributed to $U_{c r 0}$. This would bias $\beta_{2}$ away from zero and at least mitigate the positive bias.

In order to partly deal with these selection issues or omitted variable bias, we augment equation (4) with a measure of cognitive ability observed in our data:

$$
\begin{aligned}
y_{i t} & =\beta_{1}+\sum_{e} \beta_{2}^{e} U_{c r 0}+\sum_{e} \beta_{3}^{e} R_{i 1}+R_{i 1} \times \theta_{r}+R_{i 1} \times \xi_{c} \\
& +\sum_{e} \beta_{4}^{e} Q_{i}+Q_{i} \times \theta_{r}+Q_{i} \times \xi_{c}+\phi_{t}+\theta_{r}+\gamma_{e}+\gamma_{e} \times \theta_{r}+\xi_{c}+u_{i t},
\end{aligned}
$$

where $Q_{i}$ are IQ-score fixed effects for individual $i .{ }^{17}$ While the observed IQ score is potentially insufficient to fully capture individual ability, a comparison between the estimated $\beta_{2}^{e}$ from equation (5) and the estimated $\beta_{2}^{e}$ without the IQ controls nevertheless reveals useful information about the importance of selection bias because of unobserved individual ability. Heckman, Stixrud, and Urzua (2006) have shown that there is a strong correlation between IQ scores and labor market outcomes, and when IQ does not add to the explanatory power in equation (5), it seems reasonable to assume that unobserved ability factors also play a limited role.

The last column in Table 4 reports the estimates when IQ scores are controlled for as in equation (5). Compared with the estimates in column (2), the estimated coefficients on initial labor market conditions barely change. We interpret this as an indication that self-selection based on unobserved individual characteristics is unlikely to bias our results. The quality of the first employment appears to play a much larger role in explaining the long-term career loss from graduating in recessions.

To summarize, we find that skill mismatch may be important for explaining the effects of graduating in recessions. Our findings suggest that the accumulation of industry-specific human capital is an important mechanism in the recovery process. Some workers manage to switch back to their high-match-quality industry, and acquire new skills through on- the-job training. Still, for some workers who are unable to switch to the right industry, their work skills depreciate slowly over time, leading to

\footnotetext{
${ }^{17}$ They include nine dummy variables because the IQ score is reported on a nine-point standard scale based on stanine (Standard Nine) units.
} 
persistent earnings losses that are difficult to recover.

\section{Robustness Checks}

\subsection{Selectivity Over Initial Labor Market Conditions}

In the empirical analysis, we have assumed that the local unemployment rate at the time of graduation represents an exogenous labor demand shock. If college students affect the regional unemployment rate through the timing of their graduation, the initial unemployment rate is endogenous. To test whether there is selective timing of graduation, we use a variable created by Statistics Norway documenting the number of semesters a student studies beyond the program duration. From this variable, we create a dichotomous variable, $D_{i c r}$, which equals one if a college graduate $i$ delays graduation. We estimate the following individual-level regression:

$$
D_{i c r}=\alpha_{1}+\alpha_{2} U_{i c r}+\theta_{r}+\xi_{c}+v_{i c r},
$$

where $U_{i c r}$ is the unemployment rate at the predicted time of graduation for the individual (at age 23), and $\theta_{r}$ and $\xi_{c}$ are regional and cohort fixed effects, respectively. The first column in Table 5 reports the estimated coefficient $\alpha_{2}$. It is small and insignificant, suggesting little evidence of selective timing of graduation in response to local demand shocks.

In our main empirical model, $U_{i c r}$ is the region of the college from which individual $i$ graduates. If college graduates affect the regional unemployment rate by searching for employment opportunities in other regions, the initial unemployment rate may not be the most relevant determinant of the labor market outcomes. To assess the importance of this issue, we define a dummy variable $L_{i c r}=1$ if the region of residence among workers in the first year following graduation is different from the region of the school. We use $L_{i c r}=1$ as our dependent variable and estimate equation (6). Column 2 in Table 5 shows that the estimated coefficient $\alpha_{2}$ is small and insignificant. ${ }^{18}$

\footnotetext{
${ }^{18}$ In estimating our main empirical model in equation (1), we also attempted to replace the school region with the region of residence at the time of graduation and use the initial unemployment rate at the region of residence as the key independent variable. Region of residence might differ from the school region, because during most of our time period, the majority of students were still recorded in administrative registers as residing with their parents. We also experimented by clustering our preferred definition of labor market regions (at the county level) into larger labor market areas (North, Mid-north, West, South, and East). Neither of the alternatives significantly changed our previous conclusions.
} 
As a final piece of evidence that there is no selectivity on the initial labor market conditions, we re-estimate the regression as specified in equation (6) by replacing the dependent variable with the observed IQ scores $\left(Q_{i}\right)$. Column 3 in Table 5 shows that there is little evidence that observed quality varies with initial labor market conditions.

\subsection{Alternative Measure of the First Match Quality}

As a robustness check, we use another measure of match quality abstracting from the industry-specific skill premia estimated in the wage regressions. Rather than looking at wage premia, we use worker flows from graduation to the industry of the first employment to define mismatch. For each major $m$ and cohort $c$, we count the number of graduates working in each industry $j$ in the first year after graduation $\left(F_{m c}^{j}\right) .{ }^{19}$ To ensure that we are not simply picking up industries with the highest overall level of labor demand, we normalize it by total employment in industry $j$ from the same cohort $c$ in the first year since graduation, as follows:

$$
f_{m c}^{j}=\frac{F_{m c}^{j}}{\sum_{m} F_{m c}^{j}},
$$

where $f_{m c}^{j}$ is the normalized worker flow into industry $j$ for major $m$ and cohort $c$. The level of $f_{m c}^{j}$ will be affected by the absolute size of the major/cohort, but we rank $\left\{f_{m c}^{j}\right\}_{j=1}^{8}$ within major $m$ and cohort $c$ and use this rank as our alternative measure of match quality. ${ }^{20}$

Table 6 reports the long-term effects of initial unemployment rate on match quality defined by the rank of the worker flows (ranging from 1 to 8 with 8 being the highest). We find that bad initial labor market condition worsens the quality of the first match and the effects are persistent throughout the early careers. The effects are driven mainly by graduates with a private-sector major. The effects are qualitatively similar to the match quality defined by the wage premia (see columns (1)-(3) in Table

\footnotetext{
${ }^{19}$ To increase the number of observations in each cohort-industry cell, we use a moving window by combining cohorts $t-2, t-1, t, t+1$, and $t+2$. This also implies that our definition of match quality is based on a "permanent" rank of worker flows.

${ }^{20}$ Table A2 in the online appendix reports the average worker flow across different cohorts. Take graduates majoring in business as an example. 43 percent of the employment in the financial services sector (within the same cohort) are business majors, whereas only 7 percent of people working in the health and education sectors majored in business. Therefore, for business majors, the financial services sector is a better match than the health and education sectors.
} 
3), although the magnitudes are smaller.

\subsection{Isolating the Effect of Labor Market Conditions at Entry}

As first pointed out by Oreopoulos et al. (2012), the estimated parameters $\beta_{2}^{e}$ from our baseline empirical model (equation (1)) identify the long-term effects of the unemployment rate at graduation plus the weighted sum of the effect of the unemployment rates a worker faced during his career. ${ }^{21}$ It can be interpreted as the average change in earnings (or other outcome variables) from graduating in a recession, given the regular evolution of the regional unemployment rate faced afterwards. Another parameter of interest is to isolate the effect of labor market conditions at entry net of subsequent effects from exposure to a possibly prolonged recession. This also allows us to assess whether the persistent effect of aggregate unemployment rates at the time of entry differs from those experienced by more mature workers.

To this end, we follow the strategy proposed by Oreopoulos et al. (2012) and estimate the following extended model:

$$
y_{c r t}=\beta_{1}+\sum_{e} \beta_{2}^{e} U_{c r 0}+\sum_{e} \beta_{3}^{e} U_{c r 12}+\phi_{t}+\theta_{r}+\gamma_{e}+\gamma_{e} \times \theta_{r}+\xi_{c}+u_{c r t},
$$

where $U_{c r 12}=0.5 \times\left(U_{c r 1}+U_{c r 2}\right)$ and $\beta_{3}^{e}=0$ for $e=\{1,2\} .^{22}$ The inclusion of $U_{c r 12}$ controls for the effects of labor market conditions in the first two years following graduation which are highly correlated with initial labor market condition. ${ }^{23}$ We allow

\footnotetext{
${ }^{21}$ To see this, denote the effect on earnings (or other outcome variables) in experience year $e$ of the unemployment rate in the labor market during experience year $d$ by $\beta_{e, d}(d<e)$. Then, the coefficient on the initial unemployment rate in equation (1) identifies:

$$
\operatorname{plim}{\widehat{\beta_{2}}}^{e}=\beta_{2}^{e}+\sum_{d=1}^{e} \beta_{e, d} \frac{\operatorname{cov}\left(U_{c r 0}, U_{c r_{d} d}\right)}{\operatorname{var}\left(U_{c r 0}\right)}
$$

where $\beta_{e, d}$ is the effect in experience year $e$ of the unemployment rate at experience year $d$ and $U_{c r_{d} d}$ is the unemployment rate a worker was exposed to at experience year $(d)$ in the region of residence $\left(r_{d}\right)$. The second term is the sum of the persistent effects of all other unemployment rate in the $e$ years since graduation.

${ }^{22} \mathrm{We}$ use the average unemployment rate in the first and second experience year because experience is grouped every two years. In order to compare similarly defined unemployment rates, in this regression we also control for the fixed effects of region of current residence.

${ }^{23} \mathrm{We}$ only include the local unemployment rate in the first two years following graduation because they are highly correlated with initial local unemployment rate. Figure A4 in the online appendix shows the autocovariance structure between subsequent unemployment rates and the initial unemployment rate (i.e. $\operatorname{cov}\left(U_{c r 0}, U_{c r_{d} d}\right)$ ). Similar to the evidence presented in Oreopoulos et al. (2012) using Canadian data, we find that the autocovariance declines quickly to close to zero starting from three years since
} 
the coefficient on $U_{c r 12}$ to vary by potential experience (beyond the first two years), because subsequent exposure to local unemployment rate $\left(U_{c r 12}\right)$ may have its own persistent effects on the outcomes (Beaudry and DiNardo (1991)). $\beta_{2}^{e}$ identifies the impact of labor market conditions at entry abstracting from the impacts of correlated future labor market conditions.

Table 7 reports the estimated coefficients $\beta_{2}^{e}$ from equation (9). The regression estimates the persistent effect of the initial labor market conditions on log earnings, unemployment and match quality, net of its correlation with unemployment rate in the first two years since graduation. In general, compared with Table 2 and the first three columns in Table 3, the initial unemployment rate effect is reduced by labor market conditions in the first two years following graduation, but the difference is small. Interestingly, most of the effect we find, both in the short and long term, is driven by the shock at the time of graduation alone.

\section{Conclusion}

The explanations previously suggested for the long-term effects of short-term cyclical variations in labor market conditions vary from the initial quality of the firm-worker match to the pro-cyclical effect on promotion. The mechanisms proposed so far have not paid specific attention to matching supply of heterogeneous skills within graduating cohorts of graduates and the heterogeneous demand for skills across different industries. In this paper, we proposed that skill mismatch, defined as mismatch between the skills supplied by college graduates (measured by the field of study in college) and skills demanded by hiring industries, is an important mechanism behind the persistent career loss caused by graduating in recessions.

Using administrative data from Norway, we found a strong countercyclical pattern of skill mismatch among college graduates entering the labor market. Initial labor market conditions had a declining but persistent effect on match quality during the early careers of these graduates. Conditional on match quality of the first employment, the long-term effects of graduating in a recession faded out much faster, and the shortterm effects were also lower, by as much as 50 percent. Policies that aim at improving the match quality of the first employment is potentially important in helping those graduating in a recession avoid long-term career losses.

graduation. 


\section{References}

Altonji, Joseph G., Lisa B. Kahn, and Jamin D. Speer (2014). "Cashier or consultant? Entry labor market conditions, field of study, and career success," NBER Working Paper 20531, National Bureau of Economic Research.

Beaudry, Paul and John DiNardo (1991). "The effect of implicit contracts on the movement of wages over the business cycle: Evidence from micro data," Journal of Political Economy, 99(4): 665-688.

Brunner, Beatrice and Andreas Kuhn (2014). "The impact of labor market entry conditions on initial job assignment and wages," Journal of Population Economics, 27(3): $705-738$.

Burgess, Simon, Carol Propper, Hedley Rees, and Arran Shearer (2003). "The class of 1981: the effects of early career unemployment on subsequent unemployment experiences," Labour Economics, 10(3): 291-309.

Cronbach, Lee Joseph (1964). Essentials of psychological testing, Harper and Row.

Ellwood, David T. (1982). "Teenage unemployment: Permanent scars or temporary blemishes?" in Richard B. Freeman and David A. Wise (eds.), "The Youth Labor Market Problem: Its Nature, Causes, and Consequences," chapter 10, University of Chicago Press, pp. 349-390.

Frühwirth-Schnatter, Sylvia, Christoph Pamminger, Andrea Weber, and Rudolf Winter-Ebmer (2012). "Labor market entry and earnings dynamics: Bayesian inference using mixtures-of-experts markov chain clustering," Journal of Applied Econometrics, 27(7): 1116-1137.

Gardecki, Rosella and David Neumark (1998). "Order from chaos? The effects of early labor market experiences on adult labor market outcomes," Industrial and Labor Relations Review, 51(2): 299-322.

Genda, Yuji, Ayako Kondo, and Souichi Ohta (2010). "Long-term effects of a recession at labor market entry in Japan and the United States," Journal of Human Resources, 45(1): 157-196. 
Gottschalk, Peter and Michael Hansen (2003). "Is the proportion of college workers in noncollege jobs increasing?" Journal of Labor Economics, 21(2): 449-471.

Hagedorn, Marcus and Iourii Manovskii (2013). "Job selection and wages over the business cycle," American Economic Review, 103(2): 771-803.

Heckman, James J., Jora Stixrud, and Sergio Urzua (2006). "The effects of cognitive and non-cognitive abilities on labor market outcomes and social behavior," Journal of Labor Economics, 24(3): 411-482.

Hunnes, Arngrim, Jarle Møen, and Kjell G. Salvanes (2008). "Wage structure and labor mobility in Norway 1980-1997," in Edward P. Lazear and Kathryn L. Shaw (eds.), "An International Comparisons of the Structure of Wages," University of Chicago Press.

Kahn, Lisa B. (2010). "The long-term labor market consequences of graduating from college in a bad economy," Labour Economics, 17(2): 303-316.

Kondo, Ayako (2007). "Does the first job really matter? State dependency in employment status in Japan," Journal of the Japanese and International Economies, 21(3): 379-402.

Kwon, Illoong, Eva Meyersson Milgrom, and Seiwon Hwang (2010). "Cohort effects in promotions and wages," Journal of Human Resources, 45(3): 772-808.

Leuven, Edwin and Hessel Oosterbeek (2011). "Overeducation and mismatch in the labor market," Handbook of the Economics of Education, 4: 283.

Liu, Kai, Kjell G. Salvanes, and Erik Ø. Sørensen (2014). "Bad times at a tender agehow education dampens the impact of graduating in a recession," Nordic Economic Policy Review, 5(1): 51-73.

Neumark, David (2002). "Youth labor markets in the United States: Shopping around vs. staying put," Review of Economics and Statistics, 84(3): 462-482.

Oreopoulos, Philip, Till von Wachter, and Andrew Heisz (2012). "The short- and longterm career effects of graduating in a recession," American Economic Journal: Applied Economics, 4(1): 1-29. 
Oyer, Paul (2006). "Initial labor market conditions and long-term outcomes for economists," Journal of Economic Perspectives, 20(3): 143-160.

Raaum, Oddbjørn and Knut Røed (2006). "Do business cycle conditions at the time of labor market entry affect future employment prospects?" Review of Economics and Statistics, 88(2): 193-210.

Statistics Norway (1983). "Standard for næringsgruppering - standard industrial classification," Official Statistics of Norway, D383.

Statistics Norway (1994). "Standard for næringsgruppering - standard industrial classification," Official Statistics of Norway, C182.

Statistics Norway (2003). "Norwegian standard classification of education: Revised 2000," Official Statistics of Norway, C751.

Steigum, Erling (2010). "Norsk økonomi etter 1980—fra krise til suksess," Centre for Monetary Economics, BI Norwegian School of Management, Working Paper 4/10.

Stevens, Katrien (2007). "Adult labour market outcomes: The role of economic conditions at entry into the labour market," Mimeo, University College London.

Sundet, Jon Martin, Dag G. Barlaug, and Tore M. Torjussen (2004). "The end of the Flynn effect? a study of secular trends in mean intelligence test scores of Norwegian conscripts during half a century," Intelligence, 32(4): 349-362.

Sundet, Jon Martin, Kristian Tambs, Jennifer R. Harris, Per Magnus, and Tore M. Torjussen (2005). "Resolving the genetic and environmental sources of the correlation between height and intelligence: A study of nearly 2600 Norwegian male twin pairs," Twin Research and Human Genetics, 8(4): 307-311.

Thrane, Vidkunn Coucheron (1977). "Evneprøving av utskrivingspliktige i Norge 1950-53," Arbeidsrapport nr. 26, INAS (in Norwegian). 


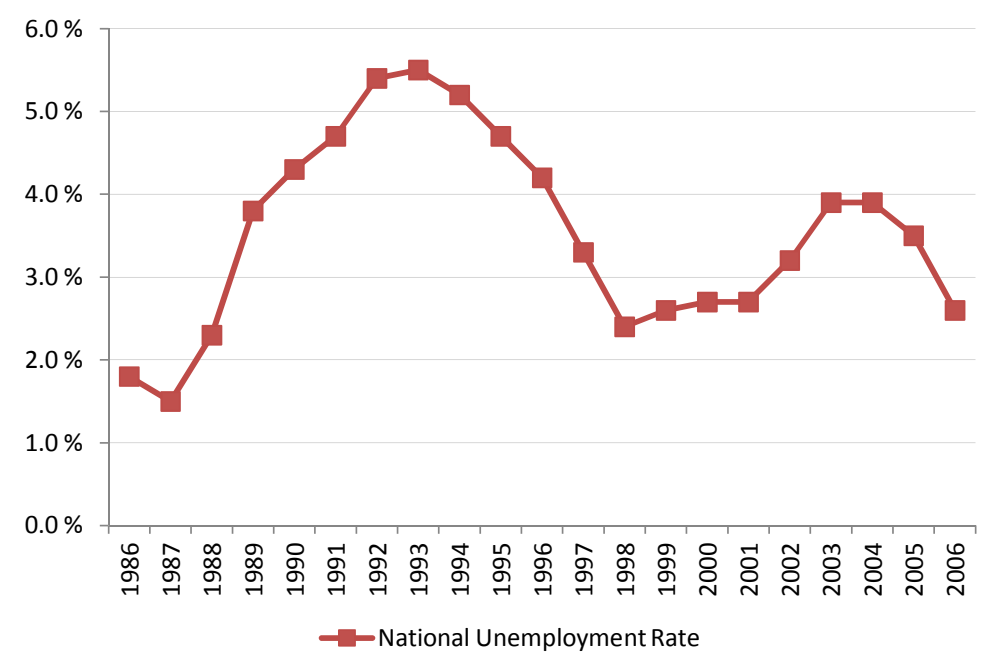

Figure 1: National Unemployment Rate in Norway, 1986-2006

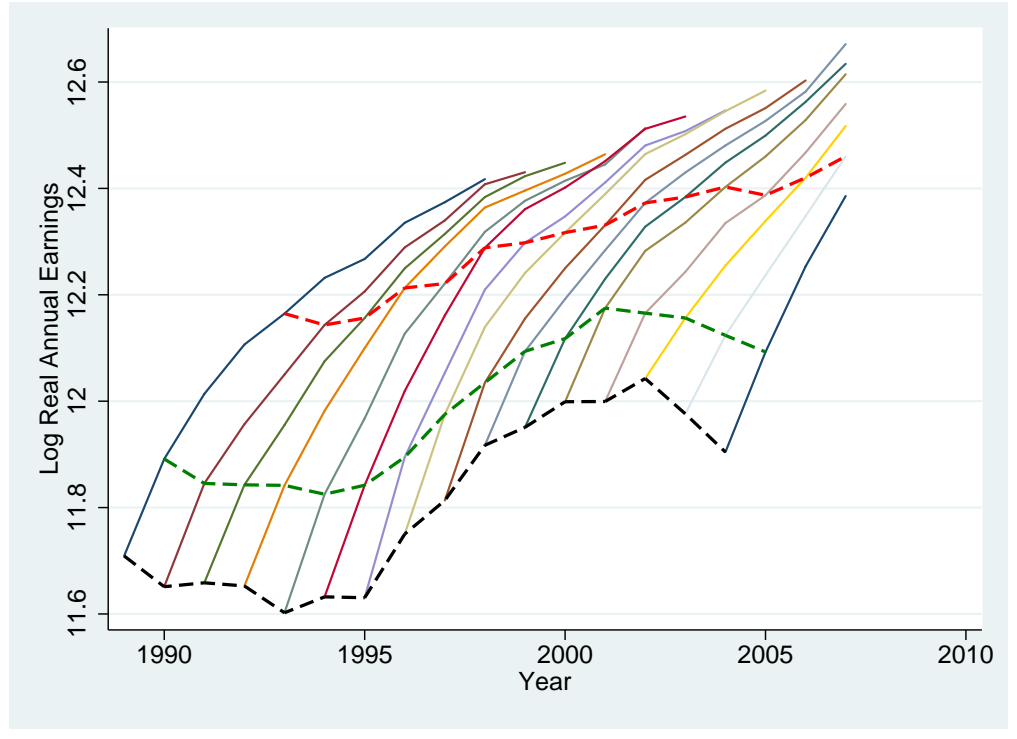

Figure 2: Experience Profiles of Log Annual Real Earnings by Cohorts 


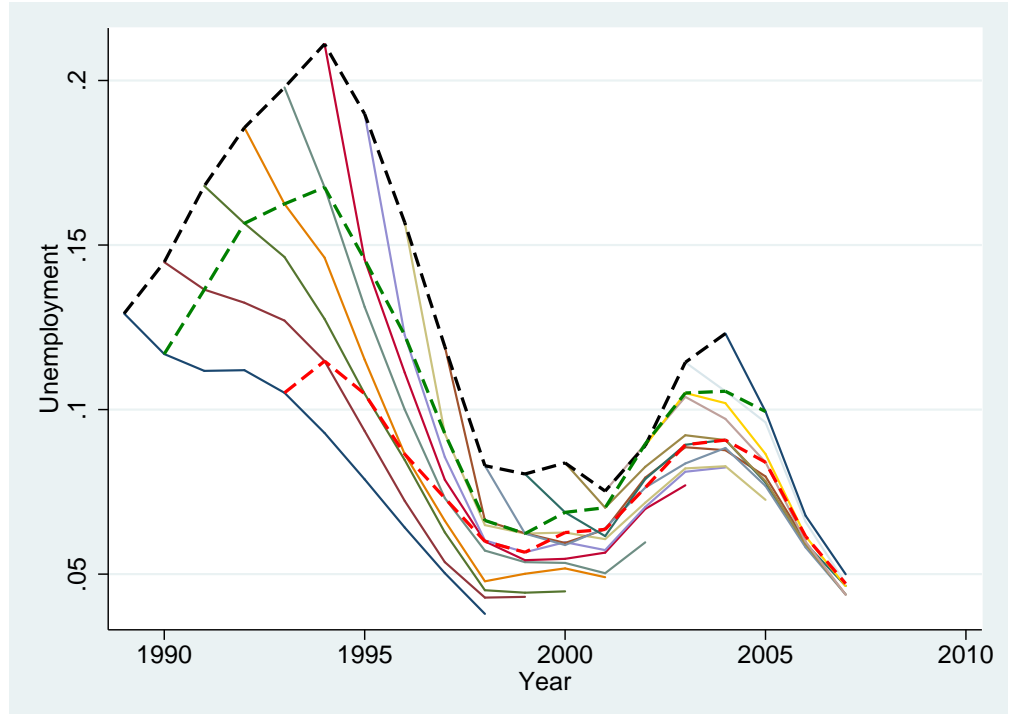

Note: Unemployment is defined as being registered as unemployed for at least one month in a year or being in one of the government-sponsored training programs targeting the unemployed.

Figure 3: Experience Profiles of Unemployment by Cohorts 

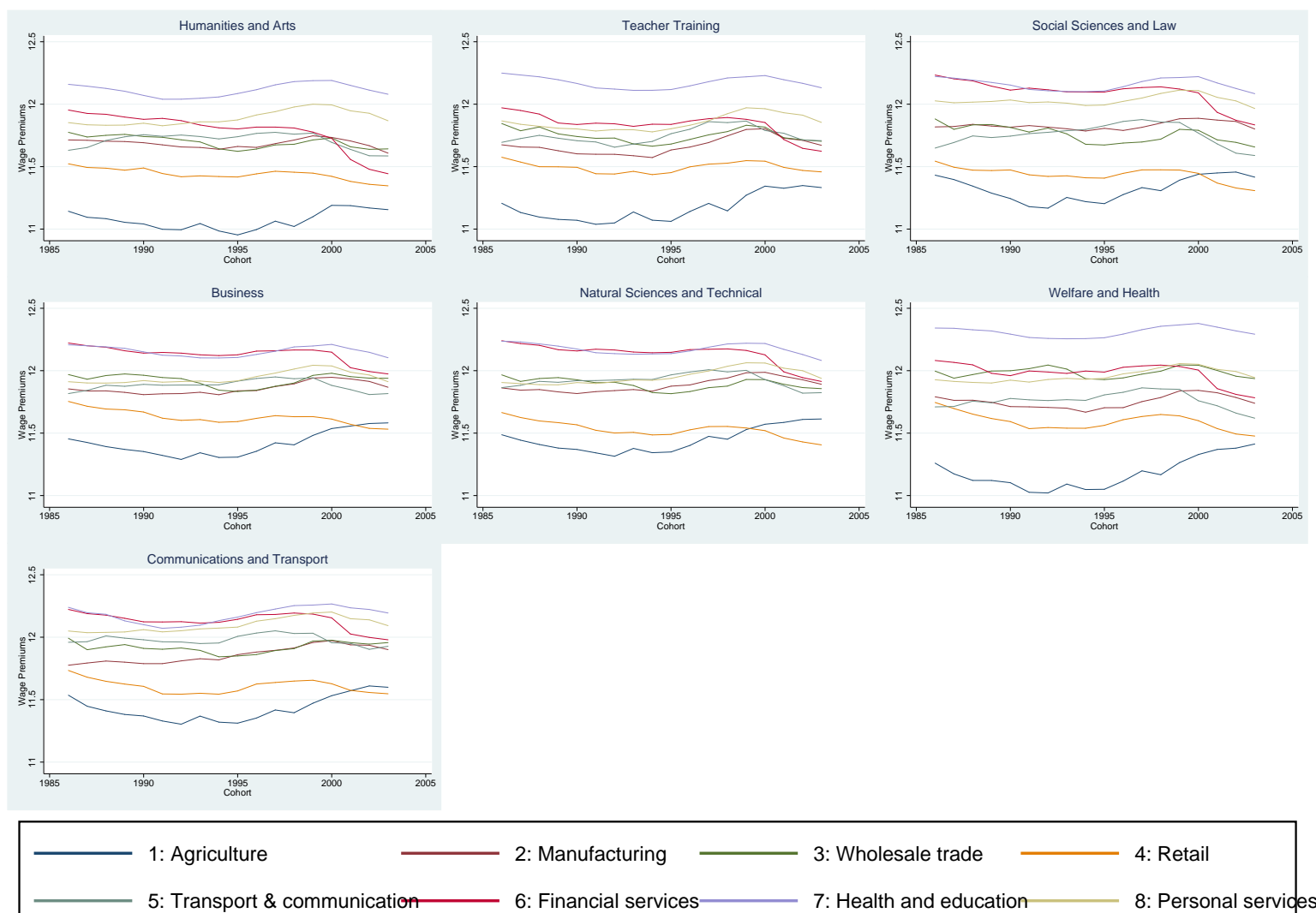

2: Manufacturing

3: Wholesale trade

4: Retail

6: Financial services-

7: Health and education

8: Personal servides

Note: Adjusted log wages are predicted from a regression of log starting annual wages (in the first year since graduation) on dummies of field of study, dummies of county of residence, full-time job dummy and female dummy. The regression is estimated separately for each industry and a graduating cohort using a five-year moving window centered around the cohort of graduation. Definitions of industry codes follow the note in Table 1.

Figure 4: Adjusted Starting Log Annual Wages by Industry and Major 


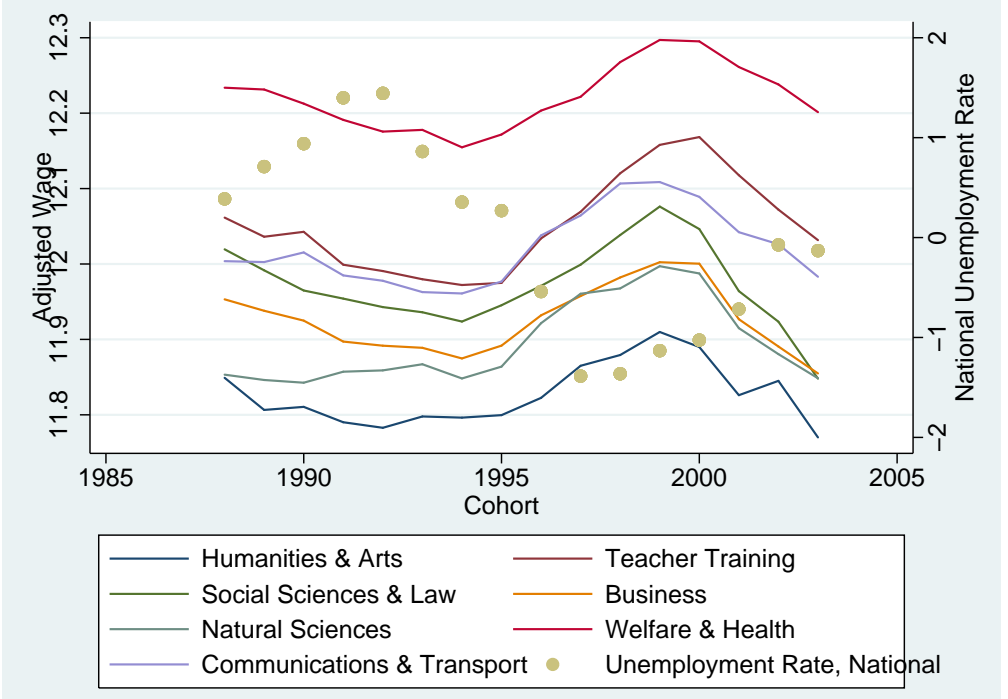

Note: This figure plots the unweighted average adjusted log wage for each field of study over all graduating cohorts. Adjusted log wages are predicted from a regression of log starting annual wages (in the first year since graduation) on dummies of field of study, dummies of county of residence, full-time job dummy and female dummy. The regression is estimated separately for each industry and a graduating cohort using a five-year moving window centered around the cohort of graduation.

Figure 5: Adjusted Starting Log Annual Wages Over Graduating Cohorts by Major 


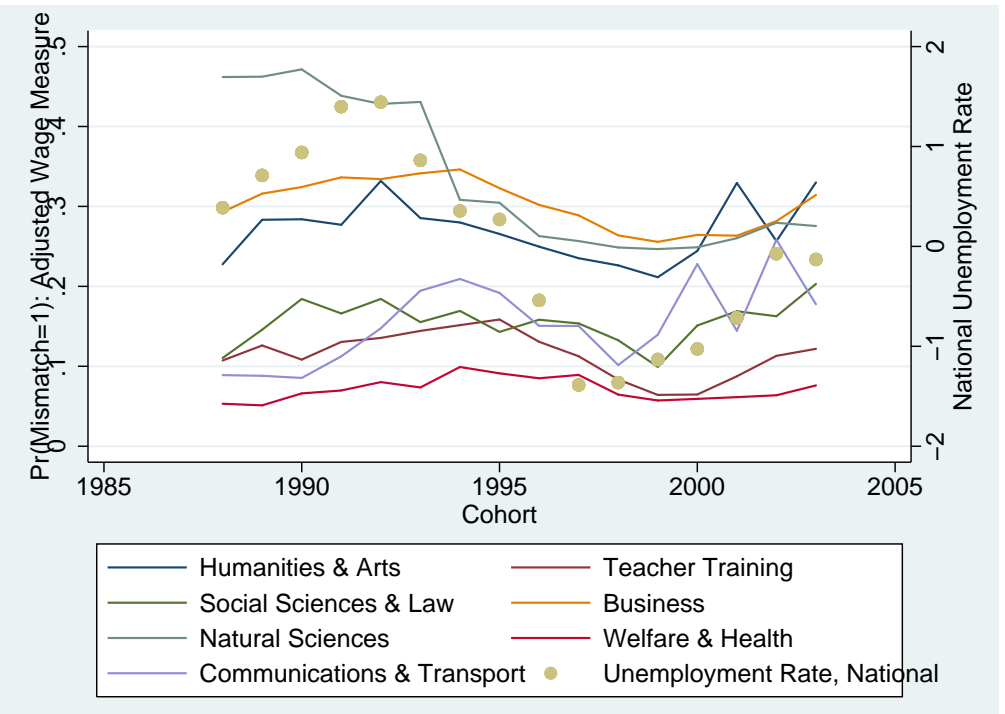

Note: This figure plots the probability of mismatch in the first year of graduation by cohort and fields of studies. The mismatch is defined based on the rank of estimated adjusted wages by cohort and major. The bottom three industries in the rank are coded as skill mismatch. Adjusted log wages are predicted from a regression of log starting annual wages (in the first year since graduation) on dummies of field of study, dummies of county of residence, full-time job dummy and female dummy. The regression is estimated separately for each industry and a graduating cohort using a five-year moving window centered around the cohort of graduation.

Figure 6: Mismatch Indicator Over Graduating Cohorts by Major 
Table 1: The Mean Adjusted Log Starting Wages by Field of Study and Industry of Initial Employment

\begin{tabular}{|c|c|c|c|c|c|c|c|}
\hline \multirow[b]{2}{*}{ Industry } & \multicolumn{7}{|c|}{ Field of study } \\
\hline & $\begin{array}{l}\text { Humanities } \\
\text { and Arts }\end{array}$ & $\begin{array}{l}\text { Teacher } \\
\text { Training }\end{array}$ & $\begin{array}{c}\text { Social Sciences } \\
\text { and Law }\end{array}$ & Business & $\begin{array}{l}\text { Natural Science } \\
\text { and Technology }\end{array}$ & $\begin{array}{c}\text { Health and } \\
\text { Welfare }\end{array}$ & $\begin{array}{c}\text { Communications } \\
\text { and Transport }\end{array}$ \\
\hline \multirow[t]{2}{*}{1} & 11.071 & 11.170 & 11.322 & 11.416 & 11.448 & 11.181 & 11.429 \\
\hline & 0.032 & 0.030 & 0.028 & 0.024 & 0.023 & 0.030 & 0.026 \\
\hline \multirow[t]{2}{*}{2} & 11.684 & 11.667 & 11.829 & 11.860 & 11.885 & 11.752 & 11.859 \\
\hline & 0.018 & 0.020 & 0.017 & 0.015 & 0.015 & 0.019 & 0.017 \\
\hline \multirow[t]{2}{*}{3} & 11.697 & 11.749 & 11.757 & 11.925 & 11.893 & 11.986 & 11.919 \\
\hline & 0.024 & 0.026 & 0.023 & 0.019 & 0.018 & 0.022 & 0.021 \\
\hline \multirow[t]{2}{*}{4} & 11.439 & 11.494 & 11.438 & 11.628 & 11.530 & 11.592 & 11.607 \\
\hline & 0.023 & 0.023 & 0.022 & 0.020 & 0.020 & 0.023 & 0.024 \\
\hline \multirow[t]{2}{*}{5} & 11.709 & 11.748 & 11.756 & 11.883 & 11.923 & 11.762 & 11.979 \\
\hline & 0.026 & 0.028 & 0.025 & 0.023 & 0.022 & 0.027 & 0.023 \\
\hline \multirow[t]{2}{*}{6} & 11.789 & 11.838 & 12.093 & 12.131 & 12.134 & 11.983 & 12.133 \\
\hline & 0.016 & 0.019 & 0.013 & 0.013 & 0.012 & 0.016 & 0.015 \\
\hline \multirow[t]{2}{*}{7} & 12.114 & 12.174 & 12.157 & 12.155 & 12.173 & 12.311 & 12.180 \\
\hline & 0.008 & 0.007 & 0.007 & 0.008 & 0.007 & 0.007 & 0.011 \\
\hline \multirow[t]{2}{*}{8} & 11.891 & 11.853 & 12.031 & 11.944 & 11.954 & 11.960 & 12.098 \\
\hline & 0.012 & 0.013 & 0.011 & 0.011 & 0.011 & 0.012 & 0.011 \\
\hline
\end{tabular}

Note: Adjusted log wages are predicted from a regression of log starting annual wages (in the first year since graduation) on dummies of field of study, dummies of county of residence, full-time job dummy and female dummy (see equation (2)). The regression is estimated separately for each industry and a graduating cohort using a five-year moving window centered around the cohort of graduation. Standard errors are shown below each estimate. Industries are defined as follows:

1-Agriculture, Hunting, Forestry and Fishing, Mining and Quarrying, Electricity, Gas and Water, Construction (ISIC, class 1, 2, 4, 5)

2-Manufacturing (ISIC, class 3)

3-Wholesale trade (ISIC, class 61) 4-Retail Trade, Restaurants and Hotels (ISIC, class 62 and 63)

5-Transport, Storage and Communication (ISIC, class 7)

6-Financing, Insurance, Real Estate and Business Services (ISIC, class 8)

7-Social and Related Community Services, including education and medical services (ISIC, class 93)

8-Community, Social and Personal Services (ISIC, class 9 excluding 93).

Starting in 1999, industry codes are mapped from the Statistics Norway (1994) standard back to the Statistics Norway (1983) standard before grouping. 
Table 2: The Effect of Initial Labor Market Conditions on Log Annual Earnings and Unemployment

\begin{tabular}{|c|c|c|c|c|c|c|}
\hline \multirow{3}{*}{$\begin{array}{c}\text { Effect by } \\
\text { Years of Potential } \\
\text { Experience }\end{array}$} & \multicolumn{3}{|c|}{ Log Earnings } & \multicolumn{3}{|c|}{ Unemployment } \\
\hline & All & Public & Private & All & Public & Private \\
\hline & (1) & (2) & (3) & (4) & (5) & (6) \\
\hline $1-2$ & $\begin{array}{c}-0.061 * * * \\
(0.008)\end{array}$ & $\begin{array}{c}-0.048 * * * \\
(0.008)\end{array}$ & $\begin{array}{c}-0.061 * * * \\
(0.010)\end{array}$ & $\begin{array}{c}0.014 * * * \\
(0.002)\end{array}$ & $\begin{array}{c}0.003 * * \\
(0.001)\end{array}$ & $\begin{array}{c}0.017 * * * \\
(0.003)\end{array}$ \\
\hline $3-4$ & $\begin{array}{c}-0.025 * * * \\
(0.007)\end{array}$ & $\begin{array}{l}-0.003 \\
(0.006)\end{array}$ & $\begin{array}{c}-0.036 * * * \\
(0.009)\end{array}$ & $\begin{array}{c}0.005 * * * \\
(0.002)\end{array}$ & $\begin{array}{l}-0.000 \\
(0.001)\end{array}$ & $\begin{array}{c}0.007 * * * * \\
(0.002)\end{array}$ \\
\hline $5-6$ & $\begin{array}{l}-0.008 \\
(0.007)\end{array}$ & $\begin{array}{c}0.019 * * * \\
(0.006)\end{array}$ & $\begin{array}{c}-0.024 * * * \\
(0.009)\end{array}$ & $\begin{array}{c}0.005 * * \\
(0.002)\end{array}$ & $\begin{array}{c}0.000 \\
(0.001)\end{array}$ & $\begin{array}{c}0.007 * * * \\
(0.003)\end{array}$ \\
\hline $7-8$ & $\begin{array}{l}-0.006 \\
(0.007)\end{array}$ & $\begin{array}{c}0.014 * * * \\
(0.005)\end{array}$ & $\begin{array}{c}-0.018 * * \\
(0.009)\end{array}$ & $\begin{array}{l}0.003^{*} \\
(0.002)\end{array}$ & $\begin{array}{l}-0.001 \\
(0.001)\end{array}$ & $\begin{array}{c}0.005^{* * *} \\
(0.002)\end{array}$ \\
\hline $9-10$ & $\begin{array}{l}-0.003 \\
(0.007)\end{array}$ & $\begin{array}{c}0.008 \\
(0.006)\end{array}$ & $\begin{array}{l}-0.008 \\
(0.010)\end{array}$ & $\begin{array}{l}-0.002 \\
(0.002)\end{array}$ & $\begin{array}{c}-0.005 * * * \\
(0.001)\end{array}$ & $\begin{array}{l}-0.001 \\
(0.002)\end{array}$ \\
\hline R-square & 0.924 & 0.893 & 0.921 & 0.859 & 0.637 & 0.861 \\
\hline Observations & 2641 & 2641 & 2641 & 2641 & 2641 & 2641 \\
\hline
\end{tabular}

Note: $* p<0.10, * * p<0.05$, *** $p<0.01$. Coefficients reported in the table are for the initial local unemployment rate measured in percentage points. Public refers to graduates majoring in Teacher Training and Pedagogy and Health, Welfare and Sport. Private refers to all other graduates. We first cluster our panel data into cells defined by cohort, calendar year, and region of graduation. We then estimate equation (1) weighted by the corresponding cell sizes. Standard errors are clustered at region of graduation and cohort level. 
Table 3: The Effect of Initial Labor Market Conditions on the Quality of the IndustryMajor Match and the Probability of Mismatch

\begin{tabular}{|c|c|c|c|c|c|c|}
\hline \multirow{3}{*}{$\begin{array}{c}\text { Effect by } \\
\text { Years of Potential } \\
\text { Experience }\end{array}$} & \multicolumn{3}{|c|}{ Match Quality } & \multicolumn{3}{|c|}{ Mismatch Indicator } \\
\hline & All & Public & Private & All & Public & Private \\
\hline & (1) & (2) & (3) & (4) & (5) & (6) \\
\hline $1-2$ & $\begin{array}{c}-0.064 * * * \\
(0.019)\end{array}$ & $\begin{array}{l}-0.006 \\
(0.013)\end{array}$ & $\begin{array}{c}-0.087 * * * \\
(0.018)\end{array}$ & $\begin{array}{c}0.021^{* * * *} \\
(0.005)\end{array}$ & $\begin{array}{c}0.003 \\
(0.002)\end{array}$ & $\begin{array}{c}0.030 * * * \\
(0.006)\end{array}$ \\
\hline $3-4$ & $\begin{array}{c}-0.038 * * \\
(0.018)\end{array}$ & $\begin{array}{c}0.016 \\
(0.013)\end{array}$ & $\begin{array}{c}-0.058 * * * \\
(0.018)\end{array}$ & $\begin{array}{c}0.017 * * * \\
(0.005)\end{array}$ & $\begin{array}{l}-0.002 \\
(0.002)\end{array}$ & $\begin{array}{c}0.025 * * * \\
(0.006)\end{array}$ \\
\hline $5-6$ & $\begin{array}{l}-0.021 \\
(0.019)\end{array}$ & $\begin{array}{l}0.024 * \\
(0.014)\end{array}$ & $\begin{array}{c}-0.040^{* *} \\
(0.019)\end{array}$ & $\begin{array}{c}0.015^{* * * *} \\
(0.005)\end{array}$ & $\begin{array}{l}-0.002 \\
(0.002)\end{array}$ & $\begin{array}{c}0.022 * * * * \\
(0.006)\end{array}$ \\
\hline $7-8$ & $\begin{array}{l}-0.015 \\
(0.020)\end{array}$ & $\begin{array}{l}0.023^{*} \\
(0.014)\end{array}$ & $\begin{array}{l}-0.027 \\
(0.021)\end{array}$ & $\begin{array}{c}0.014 * * * * \\
(0.005)\end{array}$ & $\begin{array}{l}-0.002 \\
(0.002)\end{array}$ & $\begin{array}{c}0.021 * * * * \\
(0.006)\end{array}$ \\
\hline $9-10$ & $\begin{array}{l}-0.020 \\
(0.019)\end{array}$ & $\begin{array}{c}0.018 \\
(0.014)\end{array}$ & $\begin{array}{l}-0.027 \\
(0.020)\end{array}$ & $\begin{array}{c}0.015^{* * * *} \\
(0.004)\end{array}$ & $\begin{array}{l}-0.001 \\
(0.002)\end{array}$ & $\begin{array}{c}0.021^{* * * *} \\
(0.006)\end{array}$ \\
\hline R-square & 0.864 & 0.630 & 0.894 & 0.821 & 0.521 & 0.842 \\
\hline Observations & 2641 & 2641 & 2641 & 2641 & 2641 & 2641 \\
\hline
\end{tabular}

Note: $* p<0.10, * * p<0.05$, *** $p<0.01$. Coefficients reported in the table are for the initial local unemployment rate measured in percentage points. Public refers to graduates majoring in Teacher Training and Pedagogy and Health, Welfare and Sport. Private refers to all other graduates. We first cluster our panel data into cells defined by cohort, calendar year, and region of graduation. We then estimate equation (1) weighted by the corresponding cell sizes. Standard errors are clustered at region of graduation and cohort level. 
Table 4: The Effect of Initial Labor Market Conditions on Log Annual Earnings: the Role of Initial Match Quality

\begin{tabular}{cccc}
\hline Effect by Years of & \multicolumn{3}{c}{ Log Earnings } \\
Potential Experience & $(1)$ & $(2)$ & $(3)$ \\
\hline $1-2$ & $-0.037 * * *$ & $-0.019 * * *$ & $-0.020 * * *$ \\
& $(0.009)$ & $(0.007)$ & $(0.007)$ \\
$3-4$ & $-0.029 * * *$ & $-0.014 * *$ & $-0.015 * *$ \\
& $(0.008)$ & $(0.007)$ & $(0.007)$ \\
$5-6$ & $-0.021^{* *}$ & -0.007 & -0.008 \\
& $(0.009)$ & $(0.007)$ & $(0.007)$ \\
$7-8$ & $-0.024 * * *$ & -0.009 & -0.010 \\
& $(0.008)$ & $(0.006)$ & $(0.006)$ \\
$9-10$ & $-0.020^{* *}$ & -0.006 & -0.006 \\
& $(0.008)$ & $(0.007)$ & $(0.007)$ \\
IQ & No & No & Yes \\
Match quality & No & Yes & Yes \\
\hline R-square & 0.132 & 0.182 & 0.192 \\
Observations & 694183 & 694183 & 694183 \\
\hline
\end{tabular}

Note: $* p<0.10, * * p<0.05, * * * p<0.01$. Coefficients reported in the table are for the initial local unemployment rate measured in percentage points. The sample includes all male graduates majoring in fields leading to the private sector. In columns (1)-(3), estimates are based on equations (1), (4) and (5), respectively. Standard errors are clustered at region of graduation and cohort level.

Table 5: The Correlation of Initial Labor Market Conditions with Delayed Graduation, Regional Mobility, and IQ of Graduating Cohorts

\begin{tabular}{cccc}
\hline & $\begin{array}{c}\text { Delayed Graduation } \\
(1)\end{array}$ & $\begin{array}{c}\text { Regional Mobility } \\
(2)\end{array}$ & $\begin{array}{c}\text { IQ Score } \\
(3)\end{array}$ \\
\hline Regional Unemployment Rate & -0.005 & -0.013 & -0.019 \\
& $(0.010)$ & $(0.009)$ & $(0.014)$ \\
\hline$R^{2}$ & 0.025 & 0.044 & 0.051 \\
Observations & 191969 & 214173 & 138879 \\
\hline
\end{tabular}

Note: Estimates are based on equation (6), and cohort and region fixed effects are also included in the estimation (but not reported). Coefficients reported in the table are for the initial local unemployment rate measured in percentage points. Standard errors are clustered at region of graduation. 
Table 6: The Effect of Initial Labor Market Conditions on the Quality of the IndustryMajor Match: Worker-flow Measure

\begin{tabular}{cccc}
\hline \multirow{2}{*}{$\begin{array}{c}\text { Effect by } \\
\text { Years of Potential }\end{array}$} & \multicolumn{3}{c}{ Match Quality } \\
\cline { 2 - 4 } Experience & $(1)$ & $(2)$ & $(3)$ \\
\cline { 2 - 4 } Public Majors & Private Majors \\
\hline $1-2$ & $-0.024^{*}$ & -0.001 & $-0.029^{*}$ \\
& $(0.014)$ & $(0.013)$ & $(0.018)$ \\
$3-4$ & $-0.027^{*}$ & -0.001 & $-0.034^{*}$ \\
& $(0.015)$ & $(0.013)$ & $(0.017)$ \\
$5-6$ & $-0.027^{*}$ & 0.004 & $-0.041^{* *}$ \\
& $(0.014)$ & $(0.013)$ & $(0.017)$ \\
$7-8$ & $-0.027^{*}$ & 0.008 & $-0.039^{* *}$ \\
& $(0.014)$ & $(0.014)$ & $(0.016)$ \\
$9-10$ & -0.023 & 0.006 & -0.025 \\
& $(0.014)$ & $(0.015)$ & $(0.016)$ \\
\hline R-square & 0.780 & 0.637 & 0.740 \\
Observations & 2641 & 2641 & 2641 \\
\hline
\end{tabular}

Note: $* p<0.10, * * p<0.05$, *** $p<0.01$. Coefficients reported in the table are for the initial local unemployment rate measured in percentage points. Public refers to graduates majoring in Teacher Training and Pedagogy and Health, Welfare and Sport. Private refers to all other graduates. Match quality is defined by the rank of worker flows between major and industry (see Section 5.2 for details). We first cluster our panel data into cells defined by cohort, calendar year, and region of graduation. We then estimate equation (1) weighted by the corresponding cell sizes. Standard errors are clustered at region of graduation and cohort level. 


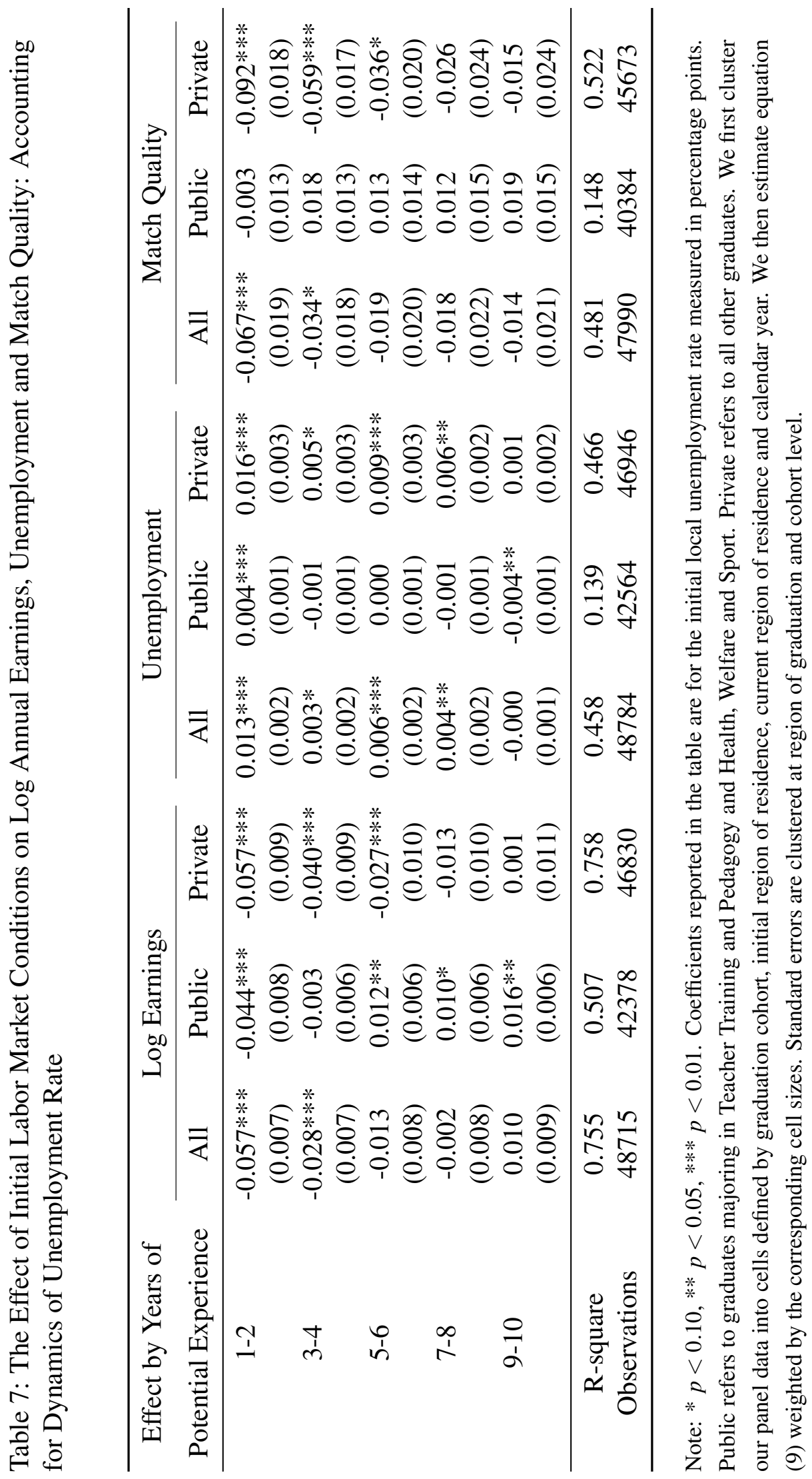




\title{
Online appendices to 'Good Skills in Bad Times: Cyclical Skill Mismatch and the Long-term Effects of Graduating in a Recession'
}

\author{
Kai Liu \\ Kjell G. Salvanes \\ Erik Ø. Sørensen*
}

May 23, 2015

\section{A How Skill Mismatch Can Arise Over the Business Cycle-An Analytical Framework}

In this section, we provide a simple analytical framework to demonstrate how skill mismatch might arise and how it relates to the business cycle: mismatch may occur throughout the cycle, but in the model counter-cyclical mismatch is inefficient. In the model, workers would like to work in the field they studied for, since this better preserves and maintains the skill they accumulated in school. Such skill dynamics are similar to those in the model of vintage human capital developed in Violante (2002), in which skills are vintage-specific to the technology in one industry. With technological progress, original skills are only partially transferable to the new technology, exhibiting as skill loss for individuals. ${ }^{1}$

Let there be two industries, 1 and 2, with a large number of firms that are homogeneous within each industry. Recent college graduates are endowed with a skill bundle $z_{i}=\left(z_{i}^{1}, z_{i}^{2}\right)$, where $z_{i}^{j}$ is the productivity of worker $i$ matched to a firm in industry $j$.

*All authors: NHH Norwegian School of Economics, Department of Economics, Helleveien 30, 5045 Bergen, Norway. Emails: Kai.Liu@nhh.no, Kjell.Salvanes@nhh.no, Erik.Sorensen@nhh.no. Corresponding author: Erik Ø. Sørensen, phone (+47) 559594 36. We thank Peter Gottschalk, Robert Moffitt, and the participants at several seminars and conferences for helpful comments and discussions. This research is supported by the Research Council of Norway Grant 202445.

${ }^{1}$ See also Neal (1995) for empirical evidence using displaced workers. 
Some graduates are ex ante more productive in the first industry $\left(z_{i}^{1}>z_{i}^{2}\right)$. Such a worker would have an ex ante expectation of working in industry 1 , and we say that such a worker has been trained for industry 1 . We shall consider it a form of mismatch if he or she works in industry 2. Similarly, the other workers are trained for industry 2.

We assume that firms are hit by an industry-wide productivity shocks, $\alpha^{j}$. This is a random variable realized in each period, that individuals can observe before they choose what industry to work in. We normalize the expectations of $\alpha^{1}$ and $\alpha^{2}$ to zero. When worker $i$ is matched to industry $j$, production is

$$
y(i, j ; \alpha)=z_{i}^{j}+\alpha^{j}
$$

We assume that workers are paid their marginal product, $w(i, j ; \alpha)=y(i, j ; \alpha)$, and allow the $\alpha$ s to be potentially correlated in the cross-section but assume that the current period realization of $\alpha$ is not informative about future values of $\alpha$.

We further assume workers to be risk-neutral, and to live for two periods. In each period, they choose one of the two states in the labor market: they work in industry 1, or they work in industry 2. Denote the choices as $D_{i t} \in\{1,2\}$. The value to a young worker $i$ of working in industry $j$ in period $t$ is

$$
V_{t}(i, j)=w_{t}\left(i, j ; \alpha_{t}\right)+\beta E_{t} \max \left\{w_{t+1}\left(i, 1 ; \alpha_{t+1}, D_{i t}\right), w_{t+1}\left(i, 2 ; \alpha_{t+1}, D_{i t}\right)\right\} .
$$

The expectation is taken with respect to the second period's realization of the industrywide productivity shock $\alpha_{t+1}$, and $\beta$ is the discount factor. The current choice can affect future wages because the evolution of skills, $z_{i t}$, might depend on the worker's choice of industry. We assume that skills that are not used depreciate at rate $\gamma$,

$$
z_{i t+1}^{j}= \begin{cases}z_{i t}^{j} \times(1-\gamma), & \text { if } D_{i t} \neq j \\ z_{i t}^{j}, & \text { if } D_{i t}=j .\end{cases}
$$

In the case of unemployment, both types of skills depreciate. ${ }^{2}$

Considering first choice in the second period, it is clear that individuals with $z^{1}(1-$ $\gamma)+\alpha^{1} \geq z^{2}+\alpha^{2}$ will be offered higher wages in industry 1 regardless of their firstperiod choice. This defines a region in which $\alpha^{2} \leq \alpha^{1}+\left(z^{1}-z^{2}\right)-\gamma z^{1}$. Similarly, if

\footnotetext{
${ }^{2}$ Note that this model is isomorphic to a model in which workers accumulate sector specific skills in the sector they work in only.
} 
$\alpha^{2} \geq \alpha^{1}+\left(z^{1}-z^{2}\right)+\gamma z^{2}$, individuals work in industry 2 regardless of their first-period choice. There is, however, a band in between, in which choice in the second period is determined by choice in the first period. This is illustrated in panel (a) of Figure A1, with the cutoffs being parallel lines with slopes of unity and vertical distance $\gamma\left(z^{2}-z^{1}\right)$. Choices in the first period have an effect on choices in the second period, so even if the realizations of $\alpha$ s are not persistent, outcomes (wages and matches to industry) will be persistent because of the skill dynamics.

Choices in the first period are made with regard to the expected depreciation of skills before entering the second period. However, because the $\alpha$ s are not persistent, the differences in future values between working in industry 1 and industry 2 today do not involve current realizations of $\alpha$. This means that the optimal cutoff in the period is a line with slope of unity in $\alpha$ space, illustrated in panel (b) of Figure A1.

Workers who graduate with skills $z_{i}^{1}>z_{i}^{2}$ expect to work in industry 1 rather than industry 2 . However, as they enter the labor market, $\alpha$ is realized, and there is some probability that wages in industry $k$ are high enough to ensure that $V(i, 2)>V(i, 1)$ even when $z_{i}^{1}>z_{i}^{2}$. We say that these individuals are efficiently mismatched when they end up working in a different industry than they trained for because of transitory shocks to the labor market. This involves no loss to society or the workers. In order to induce mismatch, current wage benefits to the mismatch must not only be positive, but also larger than the increased future depreciation of skills.

To illustrate the role of the business cycle in this model, decompose $\alpha$ such that

$$
\alpha_{t}^{j}=\zeta_{t}+v_{t}^{j}
$$

in which $\zeta_{t}$ is a cyclical factor shared by both industries and $v_{t}^{j}$ is an industry component independent of the cyclical factor. $v_{t}^{j}$. The cyclical component does not impact the difference in the value of industries 1 and 2, it shifts the $\alpha$-values parallel to the cutoffs in Figure A1, and the extent of efficient mismatch is not affected. ${ }^{3}$

In the model so far, there is no unemployment and all outcomes are efficient. But assume now that workers are credit-constrained and need to achieve a minimum consumption level $\underline{c}$, which can, if necessary, be financed with unemployment benefits (which we for simplicity also fix at $\underline{c}$ ). Now only jobs with $\alpha^{j} \geq \underline{c}-z^{j}$ are feasible

\footnotetext{
${ }^{3}$ In a modification in which industry-wide productivity works multiplicatively instead of additively as in (1) efficient mismatch would be pro-cyclical because in this form, the gains from jumping to the higher productivity sector increase with the cyclical component.
} 
matches. In Figure A2 we have drawn this for a worker trained for industry 1; the dashed lines indicate the feasibility constraints. The area $A$ is the set of $\alpha$-realizations such that neither industry can help the worker realize the minimum consumption requirement, and the worker collects unemployment benefits instead. However, there is now also a triangular area $B$ in which the worker would, barring the market inefficiencies, choose to work in industry 1 . This would induce a current period loss relative to industry 2; this loss would be part of an investment in skill maintenence. Being credit constrained, however, this worker cannot finance his or her consumption requirement while maintaining the skills he or she trained for, and is forced to work in industry 2. We say that such a worker is inefficiently mismatched.

While we saw that the cyclical component of the productivity shock shared by both sectors was neutral with respect to mismatch without market frictions, this is no longer the case with the credit constraint. In good times, the $\alpha$-realizations are moved to the northeast of Figure A2, and fewer people are forced to accept a mismatch because of credit constraints (in the $B$ area), leading inefficient mismatch to be countercyclical. If industry-specific shocks are highly correlated, we will tend to see more unemployment, because such shocks cannot be buffered by workers going to work in industries other than the ones they trained for. If the shocks are less correlated there will be more mismatches. Depreciation of skills that are not used will lead to mismatch having persistent effects even if the shocks are transitory. Mismatch will persist both with and without the presence of credit constraints, but with credit constraints there will be stronger long-term effects on realized wages because workers also accept inefficient mismatches.

In our model, much of apparent mismatch between field of study and industry of work might be efficient, and would not a concern for policymakers, but such efficient mismatch is not countercyclical. On the other hand, credit constraints and a preference for consumption smoothing (modelled as a minimum consumption requirement) leads to countercyclical and inefficient mismatch that would be cause for public concern. The complimentarity between schooling and labor market experience implies that such mismatch can have long- lasting effects even if productivity shocks are transitory.

Our model relies on a stylized and symmetric model of additive productivity shocks to sectors. While our main conclusions are robust to making the productivity shocks multiplicative, other modifications (such as including within-sector heterogeneity in labour demand with a countercyclical variance (Lilien, 1982)) could dampen and pos- 
sible reverse the implication that countercyclical mismatch is inefficient.

\section{B Potential Bias in Estimating Equation (4)}

In a multivariate context it is difficult to sign the biases of the OLS coefficient on $U_{c r 0}$. As an illustration, we derive the bias from an analysis of the OLS estimates for the following simplified equation:

$$
y_{i t}=\beta_{1}+\beta_{2} U_{c r 0}+\beta_{3} R_{i 1}+\varepsilon_{i t} .
$$

The OLS estimate for the coefficient on initial unemployment rate is:

$$
\widehat{\beta}_{2}=\beta_{2}+\frac{\widehat{\sigma}_{r r} \widehat{\sigma}_{u \varepsilon}-\widehat{\sigma}_{u r} \widehat{\sigma}_{r \varepsilon}}{\widehat{\sigma}_{u u} \widehat{\sigma}_{r r}-\widehat{\sigma}_{u r}^{2}}
$$

where $\widehat{\sigma}_{a b}$ denotes the sample covariance between variable $a$ and $b . U_{c r 0}$ is exogenous by our identifying assumption, hence $\sigma_{u \varepsilon}=0$. Therefore, the asymptotic bias is

$$
-\frac{\sigma_{u r} \sigma_{r \varepsilon}}{\sigma_{u u} \sigma_{r r}\left(1-\rho_{u r}^{2}\right)}
$$

The error term $u_{i t}$ may contain individual unobserved ability and some unobservable component of match quality between the individual and the industry of first employment. In Section 4.2, we have shown that match quality of first employment is negatively correlated with initial unemployment rate $\left(\sigma_{u r}<0\right)$. In general, we expect the correlation between the error term and match quality of first employment to be positive, $\sigma_{r \varepsilon}>0$. Taken together, these two factors lead to a positive bias of the estimated $\beta_{2}$.

\section{References}

Lilien, David M. (1982). "Sectoral shifts and cyclical unemployment," Journal of Political Economy, 90(4): 777-793.

Neal, Derek (1995). "Industry-specific human capital: Evidence from displaced workers," Journal of labor Economics, 13(4): 653-677. 
Statistics Norway (1983). "Standard for næringsgruppering - standard industrial classification," Official Statistics of Norway, D383.

Statistics Norway (1994). "Standard for næringsgruppering - standard industrial classification,” Official Statistics of Norway, C182.

Violante, Giovanni L. (2002). "Technological acceleration, skill transferability, and the rise in residual inequality," Quarterly Journal of Economics, 117(1): 297-338. 


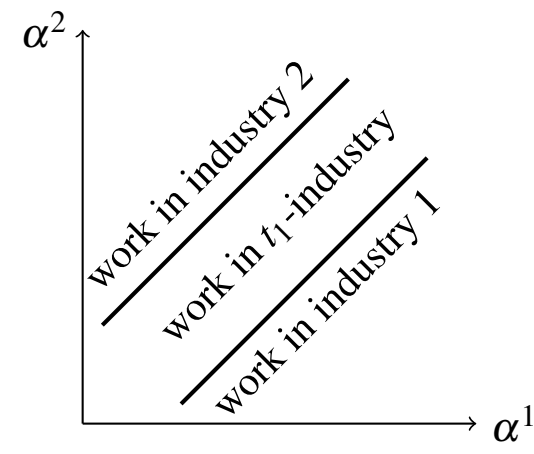

(a) 2nd period

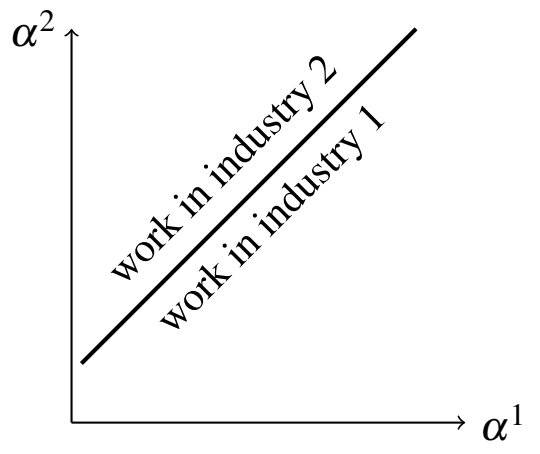

(b) 1 st period

Figure A1: Choices in first and second period in $\alpha$ space for a given $\left(z^{1}, z^{2}\right)$.

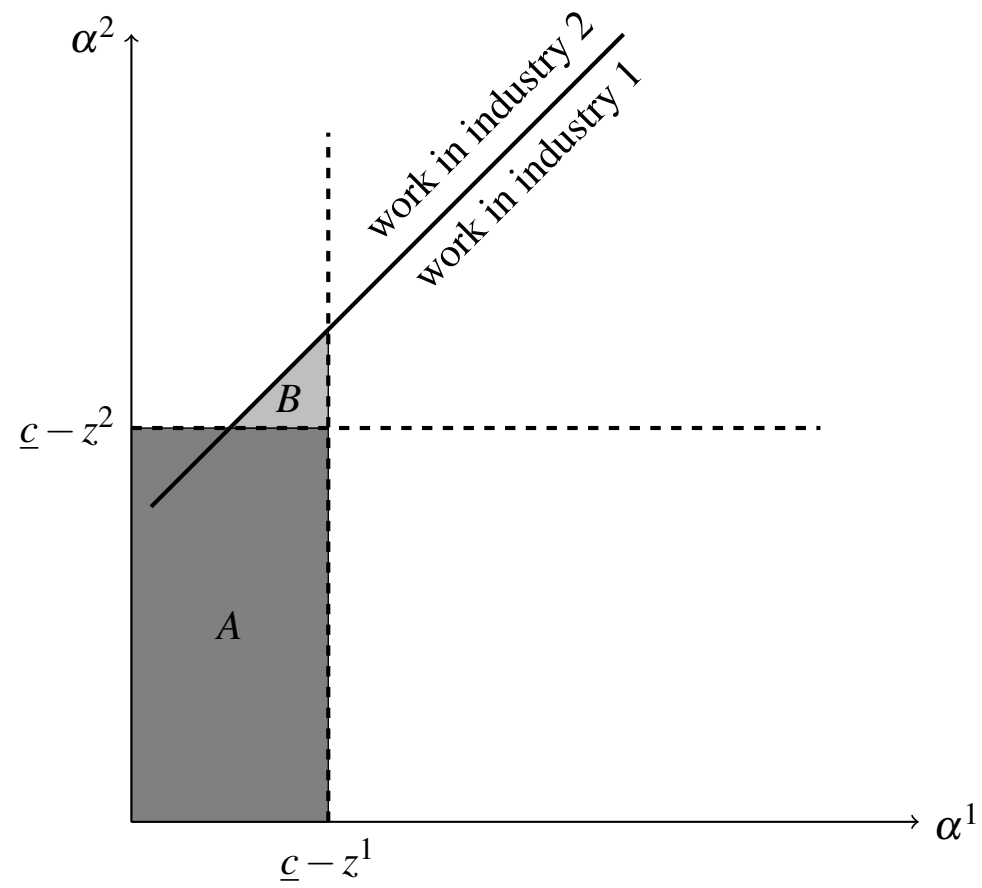

Figure A2: Unemployment and inefficient mismatch with a minimum consumption requirement for a given $\left(z^{1}, z^{2}\right)$. 


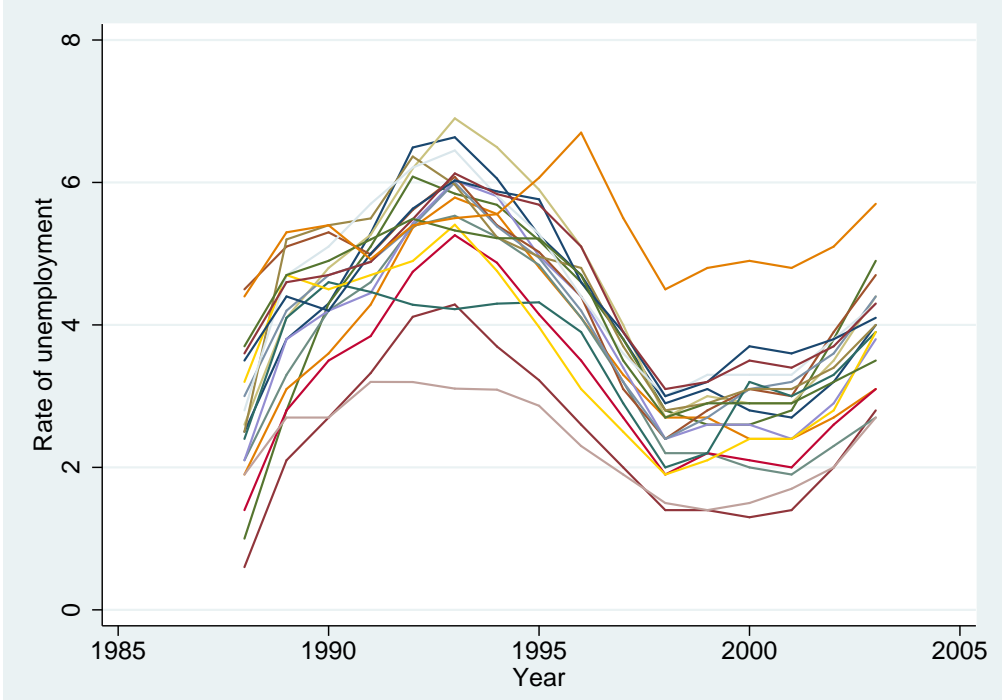

Note: The graph shows the first regional unemployment rate faced by each graduating cohort in analysis. Each solid line shows the unemployment rate in a given region over time. There are 19 regions in total.

Figure A3: Regional Unemployment Rate in Norway, by Year 


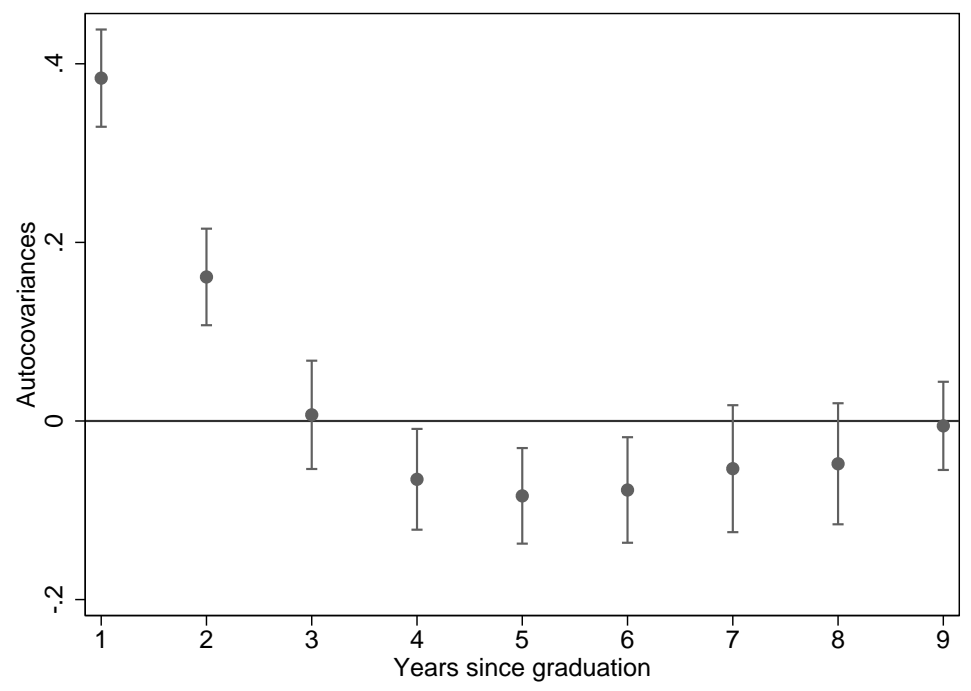

Note: This figure shows the auto-covariance structure between subsequent unemployment rates and the initial unemployment rate. They are obtained from the following regression on data collapsed at the level of graduation cohort, initial region of residence, current region of residence and calendar year:

$$
U_{c r_{e} e}=\text { cons }+\gamma_{e} U_{c r 0}+\phi_{t}+\theta_{r}+\theta_{r_{e}}+\xi_{c}+u_{c r t}
$$

where regional unemployment rates in a given experience year $\left(U_{c r_{e} e}\right)$ is regressed on the unemployment rate at graduation $\left(U_{c r 0}\right)$, fixed effects for region of the college at the time of graduation $\left(\theta_{r}\right)$, graduating cohort $\left(\xi_{c}\right)$ and current region of residence $\left(\theta_{r_{e}}\right) . \gamma_{e}$ is the estimated autocovariance of local unemployment rate at $e$ lags. The regression is weighted by the number of people in the corresponding cell.

Figure A4: Auto-covariance Structure of Local Unemployment Rate 


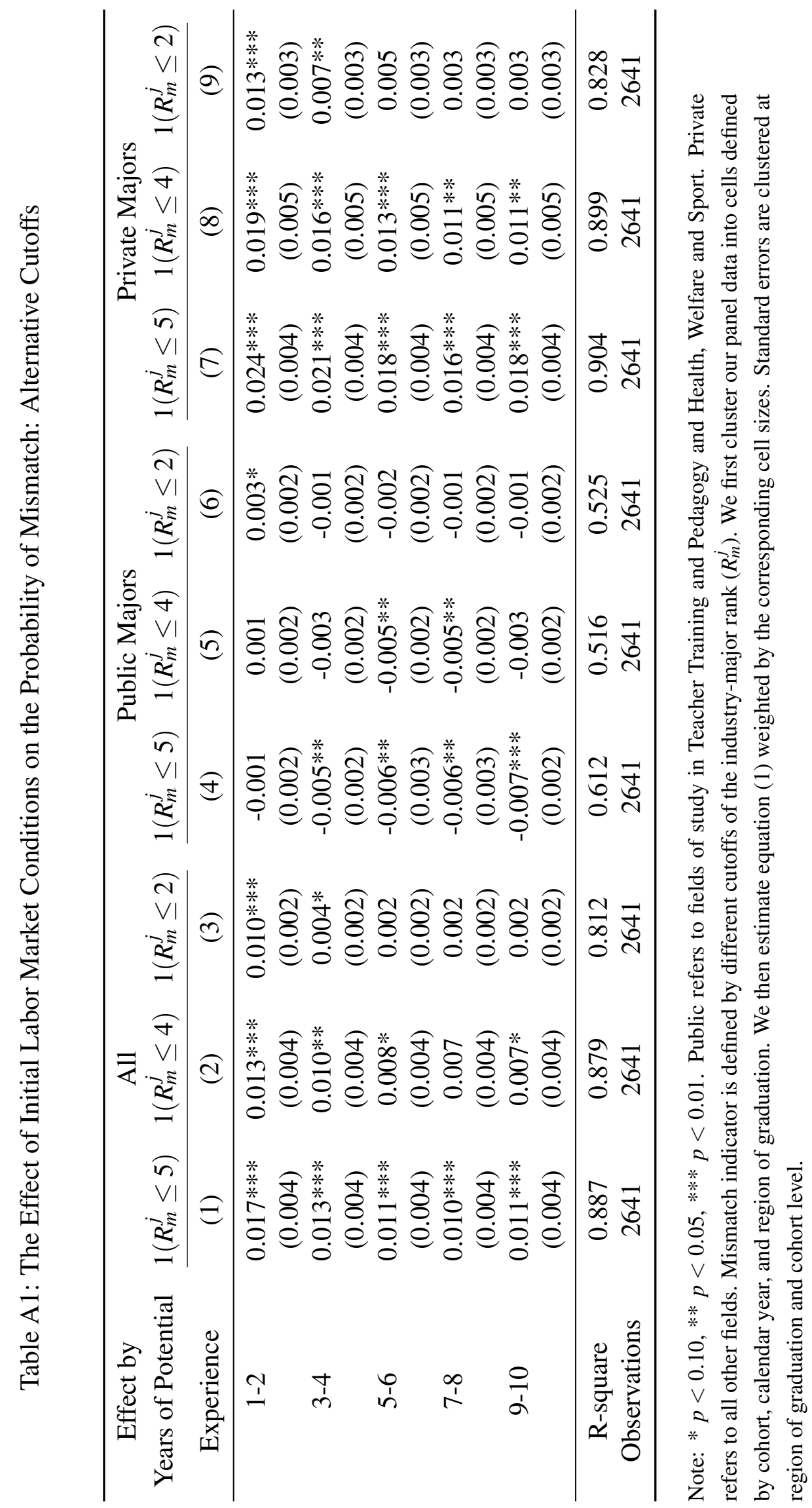


Table A2: The Mean Worker Flows by Field of Study and Industry of Initial Employment

\begin{tabular}{cccccccc}
\hline & \multicolumn{7}{c}{ Field of study } \\
\cline { 2 - 8 } Industry & $\begin{array}{c}\text { Humanities } \\
\text { and Arts }\end{array}$ & $\begin{array}{c}\text { Teacher } \\
\text { Training }\end{array}$ & $\begin{array}{c}\text { Social Sciences } \\
\text { and Law }\end{array}$ & $\begin{array}{c}\text { Natural Science } \\
\text { Business } \\
\text { and Technology }\end{array}$ & $\begin{array}{c}\text { Health and } \\
\text { Welfare }\end{array}$ & $\begin{array}{c}\text { Communications } \\
\text { and Transport }\end{array}$ \\
\hline 1 & 0.019 & 0.026 & 0.029 & 0.164 & 0.688 & 0.025 & 0.048 \\
2 & 0.037 & 0.028 & 0.050 & 0.223 & 0.580 & 0.038 & 0.044 \\
3 & 0.035 & 0.023 & 0.035 & 0.412 & 0.392 & 0.053 & 0.050 \\
4 & 0.087 & 0.089 & 0.108 & 0.377 & 0.188 & 0.108 & 0.043 \\
5 & 0.050 & 0.039 & 0.067 & 0.331 & 0.330 & 0.040 & 0.143 \\
6 & 0.031 & 0.013 & 0.096 & 0.430 & 0.376 & 0.022 & 0.032 \\
7 & 0.044 & 0.236 & 0.078 & 0.073 & 0.103 & 0.455 & 0.011 \\
8 & 0.053 & 0.049 & 0.205 & 0.175 & 0.158 & 0.078 & 0.281 \\
\hline
\end{tabular}

Worker flows between major of study and industry of first employment, normalized by the size of the industry employment. See Section 5.2 in the main paper for details. Industries are defined as follows:

1-Agriculture, Hunting, Forestry and Fishing, Mining and Quarrying, Electricity, Gas and Water, Construction (ISIC, class 1, 2, 4, 5)

2-Manufacturing (ISIC, class 3)

3-Wholesale trade (ISIC, class 61) 4-Retail Trade, Restaurants and Hotels (ISIC, class 62 and 63)

5-Transport, Storage and Communication (ISIC, class 7)

6-Financing, Insurance, Real Estate and Business Services (ISIC, class 8)

7-Social and Related Community Services, including education and medical services (ISIC, class 93)

8-Community, Social and Personal Services (ISIC, class 9 excluding 93).

Starting in 1999, industry codes are mapped from the Statistics Norway (1994) standard back to the Statistics Norway (1983) standard before grouping. 